\title{
WWLLASSIFIEU
}

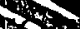

Report No. BMI-1195

C-47 Technology - Feed Materials (M-3679, 19th Ed.)

Contract No. W -7405 -eng -92

\section{NEW BETA HEAT-TREATING SALT BATHS FOR REDUCING \\ HYDROGEN PICKUP BY URANIUM RODS}

\section{by}

$\because$

Lawrence L. Lortscher

Karl A. Sense

Robert B. Filbert, Jr.
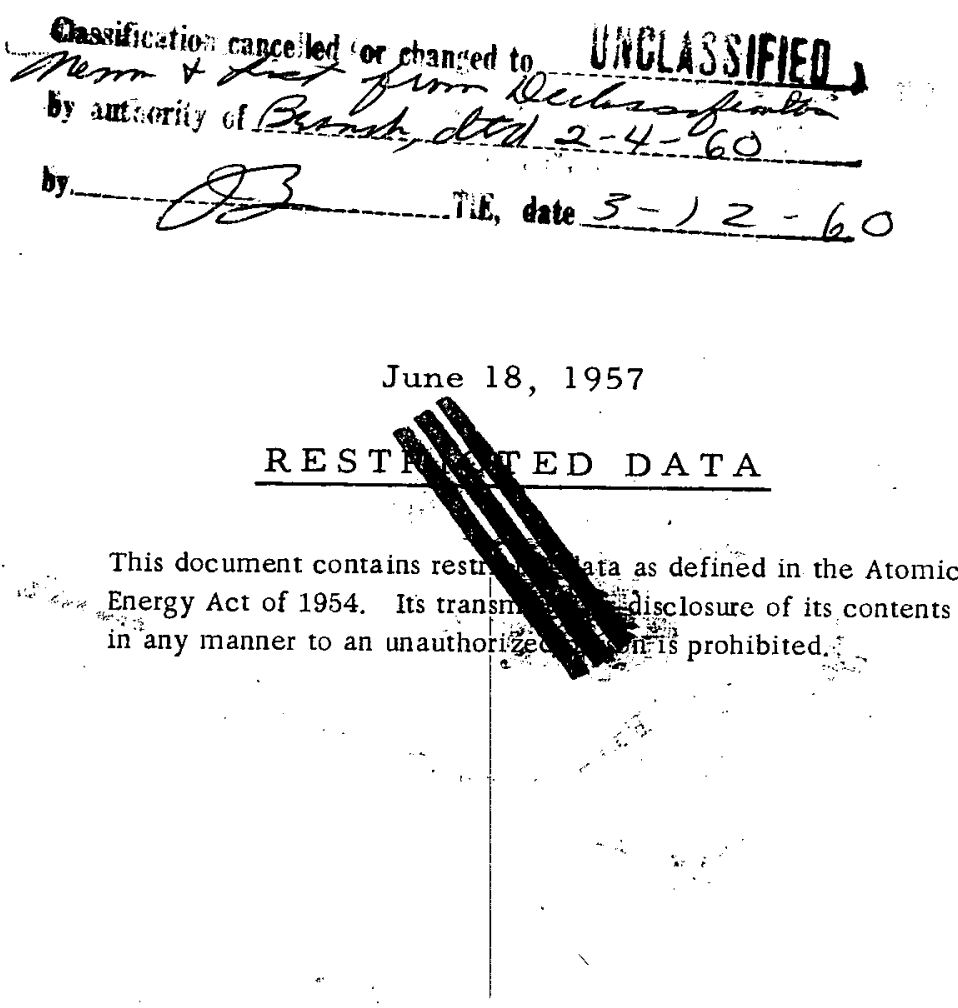

BATTELLE MEMORIAL INSTITUTE

505 King Avenue

Columbus 1, Ohio

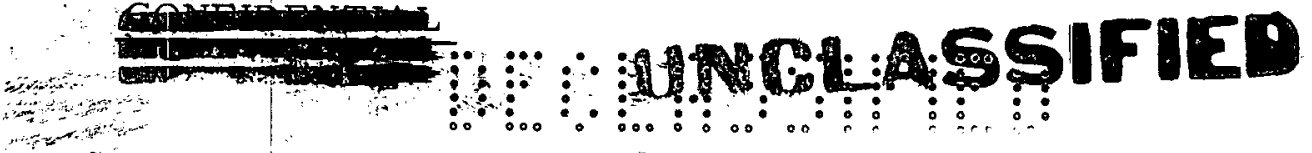




\section{DISCLAIMER}

This report was prepared as an account of work sponsored by an agency of the United States Government. Neither the United States Government nor any agency Thereof, nor any of their employees, makes any warranty, express or implied, or assumes any legal liability or responsibility for the accuracy, completeness, or usefulness of any information, apparatus, product, or process disclosed, or represents that its use would not infringe privately owned rights. Reference herein to any specific commercial product, process, or service by trade name, trademark, manufacturer, or otherwise does not necessarily constitute or imply its endorsement, recommendation, or favoring by the United States Government or any agency thereof. The views and opinions of authors expressed herein do not necessarily state or reflect those of the United States Government or any agency thereof. 


\section{DISCLAIMER}

Portions of this document may be illegible in electronic image products. Images are produced from the best available original document. 


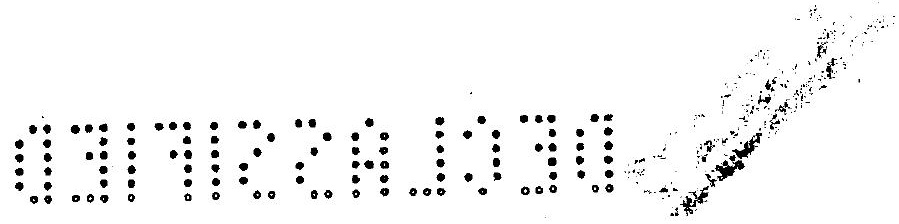


Description of Procedures . . . . . . . . . . . . . . . . . . . 6

Two-Day Aging Procedure . . . . . . . . . . . . . . . 6

Five to Seven-Day Aging Procedure . . . . . . . . . . . . 7

Continuous Aging Under Room Atmosphere . . . . . . . . . 7

Results of Tests . . . . . . . . . . . . . . . . . . . . 8

The Dependence of Hydrogen Pickup on Type of Salt Mix . . . . $\quad 8$

The Dependence of Hydrogen Pickup on Humidity . . . . . . . 12

The Effect of Hydroxyl-Ion Concentration on Hydrogen Pickup . . . 12

Uranium-Specimen Corrosion .

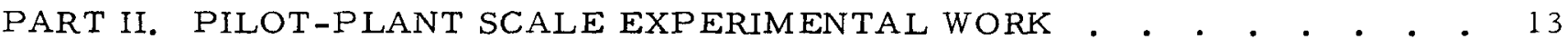

Description of Procedure . . . . . . . . . . . . . . . . . 13

Experimental Results . . . . . . . . . . . . . . . . . . . 14

Dependence of Hydrogen Pickup on Type of Salt Bath . . . . . . 15

Hydrogen Pickup Compared With the Effect of Humidity,

Salt-Bath Age, Type of Contaminant, and Salt-Bath

Alkalinity on Hydrogen Pickup . . . . . . . . . . . . . 17

Adherence of Salt to Uranium Following Quench . . . . . . . . 17

Preliminary Study of Materials Corrosion . . . . . . . . . . 19

\section{APPENDIX A}

DATA FOR PART I

APPENDIX B

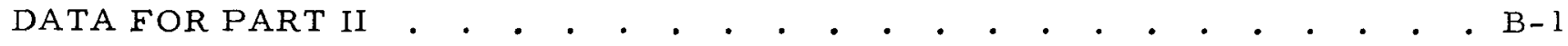




\title{
NEW BETA HEAT-TREATING SALT BATHS FOR \\ REDUCING HYDROGEN PICKUP BY URANIUM RODS
}

Lawrence L. Lortscher, Karl A. Sense, and Robert B. Filbert, Jr.

\begin{abstract}
Hydrogen pickup by uranium was studied in different salt mixtures at $1350 \mathrm{~F}$ under dry and wet atmospheres. Laboratory-scale work showed that of the salts investigated, $50 \mathrm{w} / \mathrm{o} \mathrm{KCl}-50 \mathrm{w} / \mathrm{o} \mathrm{NaCl}$ and $50 \mathrm{w} / \mathrm{o} \mathrm{KCl}-50 \mathrm{w} / \mathrm{o} \mathrm{Na}{ }_{2} \mathrm{CO}_{3}$ gave the best results from the standpoint of low hydrogen pickup, corrosion of uranium, and salt stability at $1350 \mathrm{~F}$. These salt mixtures resulted in hydrogen pickup of less than 3 ppm under dry atmospheres and less than $5 \mathrm{ppm}$ under wet atmospheres. By comparison, the two salt mixtures which National Lead of Ohio has used in its plant, $44 \mathrm{w} / \mathrm{o} \mathrm{Li}_{2} \mathrm{CO}_{3}-56 \mathrm{w} / \mathrm{o} \mathrm{K}_{2} \mathrm{CO}_{3}$ and $25 \mathrm{w} / \mathrm{o}$ $\mathrm{Li}_{2} \mathrm{CO}_{3}-75 \mathrm{w} / \mathrm{o} \mathrm{K} \mathrm{CO}_{3}$, resulted in hydrogen pickup greater than $5 \mathrm{ppm}$ under dry atmospheres and as high as 13 ppm under wet atmospheres. Pilot-plant-scale studies showed that the average final hydrogen content of the uranium specimens treated in the $50 \mathrm{w} / \mathrm{o}$ $\mathrm{KCl}-50 \mathrm{w} / \mathrm{o} \mathrm{NaCl}$ baths was $0.47 \mathrm{ppm}$. The corresponding average for the $50 \mathrm{w} / \mathrm{o} \mathrm{KCl}-50$ $w / o \mathrm{Na}_{2} \mathrm{CO}_{3}$ baths was $0.77 \mathrm{ppm}$. Preliminary studies of corrosion of materials of construction in the pilot-plant-scale baths indicated that Type 330 stainless steel was more resistant to attack than mild steel and Types 304, 416, and 446 stainless steels.
\end{abstract}

\section{INTRODUCTION}

At the request of the National Lead Company of Ohio (NLO), Battelle has beer. searching for a salt-batch composition that will reduce the hydrogen pickup by uranium rods during the beta heat treatment. A secondary objective was to study the influence of humidity over the salt bath on hydrogen pickup. The lithium carbonate-potassiurn carbonate salt mixture used by NLO has resulted in high hydrogen pickup and consequently abnormal rejection of the uranium during humid summer months. This report summarizes the results of both the laboratory-scale work (Part I) and the pilot-plantscale work (Part II).

\section{PART I. LABORATORY-SCALE EXPERIMENTAL WORK}

The experimental work consisted of heat treating uranium specimens in different salt mixes at $1350 \mathrm{~F}$ under various conditions to determine which salt mixes might result in lower hydrogen pickup by the uranium and to determine the dependence of hydrogen pickup on humidity. The salts used for the experimental work were selected with the following criteria in mind:

(1) Low moisture pickup at $1350 \mathrm{~F}$

(2) Corrosion of the salt-bath shell

(3) Corrosion of the salt-bath electrodes

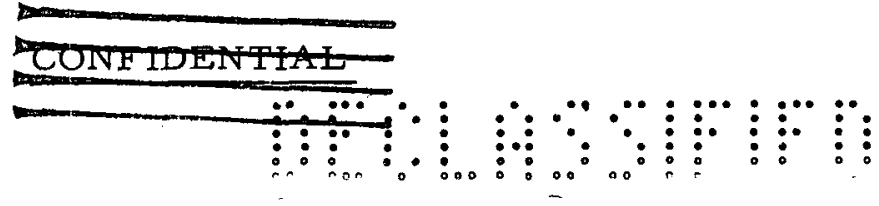




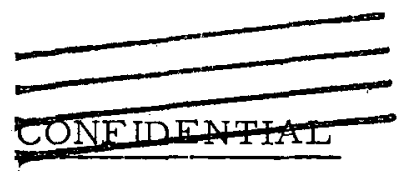

6

(4) Ease of removing salt crust adhering to uranium rods after treatment in salt bath

(5) Corrosion caused by any residual salt carried to mill equipment and machine shop

(6) Low neutron cross section of component salts

(7) Cost of salt mixture

(8) Availability of salt components

(9) Corrosion of uranium in the salt bath

(10) Dragout loss of salt.

Carbonates, chlorides, bromides, sulfates, phosphates, and silicates were considered. Sulfates and phosphates were eliminated on the basis of thermodynamic calculations which indicated that they would have excessive moisture pickup at $1350 \mathrm{~F}$. Silicates were eliminated because their low electrical conductance would make it difficult to heat the salt bath and because their high viscosity at $1350 \mathrm{~F}$ would cause excessive dragout of the salt bath. The preliminary studies indicated that chlorides, bromides, and carbonates warranted actual laboratory testing.

Three test procedures were devised in the course of this study to determine the most promising salt mixture and the significance of various operating variables. The three test procedures differed in the time salt mixes were aged prior to heat treating the uranium specimens and in the control of operating variables. The operating variables considered were atmospheric moisture, hydroxyl-ion content of the salt bath, and age of salt bath.

Description of Procedures

The heat-treating procedure common to all tests consisted of immersing weighed uranium specimens for $\mathrm{l} \mathrm{hr}$ at $1350 \mathrm{~F}$ in the salt mix to be tested, quenching in dis tilled water, visually examining the surface, weighing, and analyzing for hydrogen content. The uranium specimens were $1 / 2$-in. pieces of $1 / 4$-in. rod outgassed to less than 0.1 ppm hydrogen.

The three different test procedures used during the course of the work are described below.

Two-Day Aging Procedure

In this test procedure, fused salt mixes were maintained at $1350 \mathrm{~F}$ for 2 days prior to heat treating in a muffle furnace having an atmosphere with approximate water vapor partial pressures of $0,10,20$, or $30 \mathrm{~mm}$ of mercury. The reason for this procedure was to let the salt mixes come to equilibrium with the particular atmospheric 


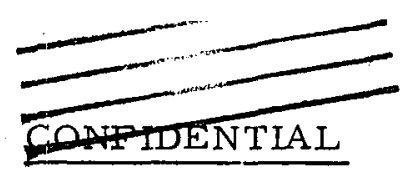

condition chosen. For most of the tests, porcelain crucibles that contained $8 \mathrm{~g}$ of each salt mix were used.

The results with this procedure indicated that the agirig period was not long enough to establish equilibrium between the fuised salt mix and the atmosphere.

Five to Seven-Day Aging Procedure

In an effort to improve the correlation between atmospheric humidity and hycrogen pickup, the salt mixes were aged for 5 to 7 days under controlled conditions. The following procedure was used for these tests. Two different salt compositions were used for one run, three samples of each composition being placed in each of two furnaces. The furnace temperatures were maintained at $600 \mathrm{~F}$ overnight to dry the salts and were then increased to $1350 \mathrm{~F}$. In one furnace the partial pressure of wate $r$ in the atmosphere was maintained at $70 \mathrm{~mm}$ of mercury, while in the other furnace it was held at $0.5 \mathrm{~mm}$ of mercury. These two extremes were chosen so that any correlation between atmospheric moisture and hydrogen pickup would become more obvious. A.fter 5 to 7 days, uranium specimens were immersed for $1 \mathrm{hr}$ in two of the three samples of each salt composition in each furnace followed by the usual steps. This procedure afforded an opportunity to compare the hydroxyl-ion concentrations of salt baths before and after heat treating uranium. Because of the porosity of the ceramic walls, nickel liners were installed in the muffle furnaces for better control of atmospheric humidity. In some of the tests $\mathrm{KOH}$ was added to the salt mix to study the dependence of hydrogen pickup on the hydroxyl-ion concentration. After some initial tésts on samples which had $\mathrm{KOH}$ added, $\mathrm{CO}_{2}$ was removed from the atmosphere to prevent the reaction of $\mathrm{KOH}$ with atmospheric $\mathrm{CO}_{2}$ to give $\mathrm{K}_{2} \mathrm{CO}_{3}$.

Porcelain crucibles were used at the beginning of this procedure. Later, platinum crucibles were used because they reduced the loss of the fused salt mix due to creeping. Erratic hydrogen pickups and excessive weight losses were obtained when all-chloride salt mixes were used in the platinum crucibles. To overcome this problem, Vycor holders were placed in the crucibles in subsequent tests to prevent direct contact between the uranium specimens and the platinum crucibles.

\section{Continuous Aging Under Room Atmosphere}

This procedure was devised to determine the hydrogen pickup resulting from aging in room atmosphere and to test the effect of extended aging of fused salt mixes.

Four Vycor tubes, open to the room atmosphere and each containing a different salt mix, were maintained at $1350 \mathrm{~F}$. Uranium specimens were treated at 7-day intervals. Salt samples were also taken at 7-day intervals and analyzed for hydroxylion content.

The test was maintained for 7 weeks; then, a power failure occurred which resulted in the loss of two of the salt mixes. The test was started again with two new Vycor tubes and three Type 304 stainless steel tubes. The two saved salt mixes were placed in the Vycor tubes, and three new salt mixes were placed in tubes constructed of Type 304 stainless steel. After 1 week of operation the salt mixes in the stainless

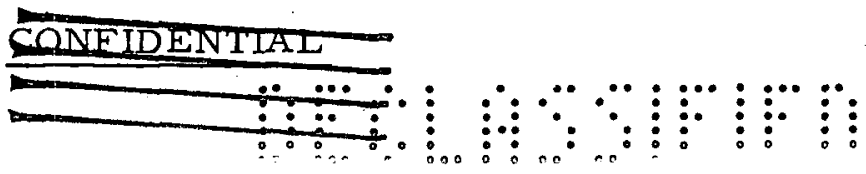




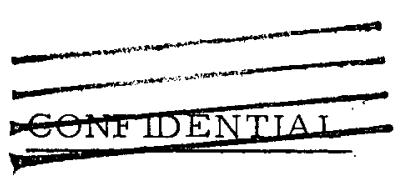

8

steel tubes become discolored. The stainless steel tubes were replaced with mild-steel tubes, and the experiment was continued for an additional 2 weeks.

$\underline{\text { Results of Tests }}$

Hydrogen pickup and weight-loss results obtained from the uranium specimens treated are compared below with the type of salt mix, atmospheric humidity, and hydroxyl-ion concentration of the fused salt mix. The complete data are recorded in Table A-2 of Appendix A.

The Dependence of Hydrogen Pickup on Type of Salt Mix

The hydrogen-pickup results obtained in the initial work done with the 2-day aging procedure are listed in Table 1. Salt Mix 4 was the standard of comparison, since it was being used in the Sponsor's plant.

Of the salt mixtures listed, Mixes 3, 10, and 15 were eliminated from further consideration because of high hydrogen pickup. Also eliminated were Mix 7 because it fumed excessively, Mix 8 because of its reaction with uranium, and Mixes 11 and 13 because they caused pitting of the uranium samples. Salt Mix 6 also produced pitting in the uranium but was tested further because of general interest, as was Salt Mix 14. The salt mixture used by NLO, Mix 4, did not show up very well. Salts also considered but eliminated from further study because of their instability at $1350 \mathrm{~F}$ were 44 w/o $\mathrm{NaCl}-56 \mathrm{w} / \mathrm{o} \mathrm{MgCl}_{2}$ and $17.6 \mathrm{w} / \circ \mathrm{NaCl}-82.4 \mathrm{w} / \circ \mathrm{CuCl}_{2}$. Best results were obtained with the $50 \mathrm{w} / 0 \mathrm{KCl}-50 \mathrm{w} / \mathrm{o} \mathrm{Na}_{2} \mathrm{CO}_{3}$ and $50 \mathrm{w} / 0 \mathrm{KCl}-50 \mathrm{w} / 0 \mathrm{NaCl}$ mixtures, since low hydrogen pickup resulted without pitting of uranium.

Salt Mixes 4, 5, 9, and 14 as well as new compositions considered worth investigating, were aged 5 to 7 days prior to immersing the uranium specimens. The results, given in Table 2, continued to show low hydrogen pickup by the uranium in Salt Mix 5 ( $50 \mathrm{w} / \mathrm{o} \mathrm{KCl}-50 \mathrm{w} / 0 \mathrm{Na}_{2} \mathrm{CO}_{3}$ ). Salt $\mathrm{Mix} 9$ showed very low average hydrogen pickup by the uranium when a porcelain crucible was used; however, when the uranium was in direct contact with a platinum crucible, the average hydrogen pickup was significantly higher. The use of Vycor holders to prevent contact between the uranium and the platinum crucibles did reduce the average hydrogen pickup somewhat for the $50 \mathrm{w} / \mathrm{OKCl}-50$ w/ $\mathrm{NaCl}$ composition. For the other compositions there was no clear benefit from the use of Vycor holders. The fact that for Salt Mix 14 a dry atmosphere led to a greater hydrogen pickup than a wet atmosphere is not understood. The very low hydrogen pickup results obtained with the $\mathrm{KCl}-\mathrm{NaCl}$ salt mix (less than $1.0 \mathrm{ppm}$ ) in porcelain crucibles, and in some cases in the Vycor holders, makes this salt mix, as well as Mixes 5 and 17 , appear very promising for low hydrogen pickup.

Figure 1 shows the hydrogen-pickup results obtained with different salt mixes that were run continuously with uranium specimens immersed at 7 -day intervals. These results confirm the preliminary low results obtained with Salt Mixes 9 (50 w/o $\mathrm{KCl}-50 \mathrm{w} / \circ \mathrm{NaCl}$ ) and 5 ( $50 \mathrm{w} / \circ \mathrm{KCl}-50 \mathrm{w} / \circ \mathrm{Na}_{2} \mathrm{CO}_{3}$ ). The high hydrogen pickup obtained with Salt Mix 9 at the third week remains unexplained. Salt Mix 6 continued

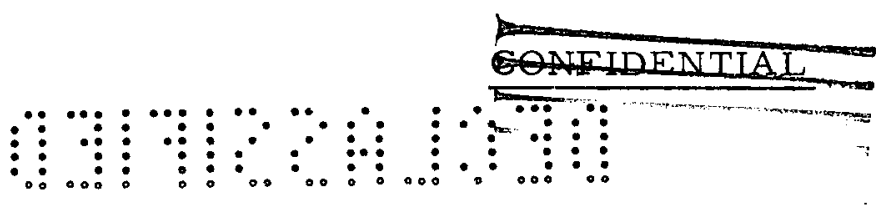




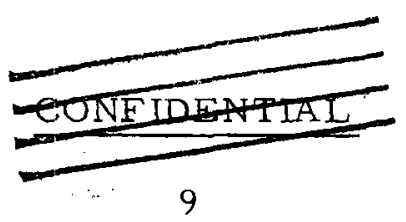

TABLE 1. HYDROGEN PICKUP BY URANIUM SPECIMENS TREATED (a)

IN DIFFERENT SALT MIXES THAT WERE AGED 2 DAYS

UNDER ATMOSPHERES WITH DIFFERENT HUMIDITIES

\begin{tabular}{|c|c|c|c|c|c|}
\hline \multirow[b]{2}{*}{ Salt Mix } & \multirow[b]{2}{*}{ Composition, w/o } & \multicolumn{4}{|c|}{$\begin{array}{l}\text { Hydrogen Pickup, ppm, at Indicated } \\
\text { Atmospheric Humidity, mm mercury }\end{array}$} \\
\hline & & 0 & 10 & 20 & 30 \\
\hline 3 & $44 \mathrm{Li}_{2} \mathrm{CO}_{3}-56 \mathrm{Na}_{2} \mathrm{CO}_{3}$ & $7.6(\mathrm{~b})$ & $6.2(\mathrm{~b})$ & $9.2^{(b)}$ & $8.7^{(b)}$ \\
\hline 4 & $44 \mathrm{Li}_{2} \mathrm{CO}_{3}-56 \mathrm{~K}_{2} \mathrm{CO}_{3}$ & 7.8 & 10.6 & 9.1 & 9.7 \\
\hline 5 & $50 \mathrm{KCl}-50 \mathrm{Na}_{2} \mathrm{CO}_{3}$ & 3.7 & 3.9 & 3.9 & 4.1 \\
\hline 6 & $24 \mathrm{NaCl}-28 \mathrm{KCl}-48 \mathrm{BaCl}_{2}$ & $1.3(\mathrm{c})$ & -- & -- & 1.5 \\
\hline 7 & $22.5 \mathrm{NaBr}-77.5 \mathrm{LiBr}$ & 1.9 & -- & -- & 2.4 \\
\hline 8 & $26.5 \mathrm{~K}_{2} \mathrm{SO}_{4}-73.5 \mathrm{Li}_{2} \mathrm{SO}_{4}$ & -- & - & $--(d)$ & $\cdots-$ \\
\hline 9 & $50 \mathrm{KCl}-50 \mathrm{NaCl}$ & $0 . \dot{9}$ & 1.0 & 1.0 & 1.4 \\
\hline 10 & $53.8 \mathrm{KCl}-46.2 \mathrm{LiCl}$ & 7.5 & 8.5 & 4.2 & 6.5 \\
\hline 11. & $32.8 \mathrm{NaCl}-67.2 \mathrm{CaCl}_{2}$ & 5.0 & -- & 4.7 & 4,5 \\
\hline 13 & $21 \mathrm{NaCl}-48 \mathrm{CaCl}_{2}-31 \mathrm{BaCl}_{2}$ & 4.9 & 3.0 & -- & $\cdots$ \\
\hline 14 & $50 \mathrm{KCl}-25 \mathrm{LiCl}-25 \mathrm{NaCl}$ & 3.8 & -- & 2.9 & 9.5 \\
\hline 15 & $70 \mathrm{KCl}-30 \mathrm{LiCl}$ & 3.4 & -- & 5.1 & 9.6 \\
\hline
\end{tabular}

(a) Uranium specimens treated for 1 hour at $1350 \mathrm{~F}$ and quenched in water. Salt mix contained in porcelain crucible, except where noted otherwise.

(b) Contained in mild-steel crucibles.

(c) Contained in a silver crucible.

(d) Uranium completely lost by reaction with salt.

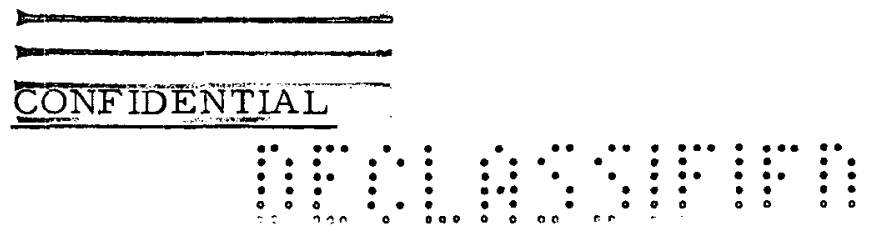




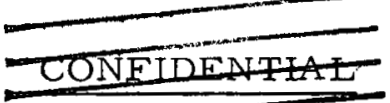

10

TABLE 2. AVERAGE HYDROGEN PICKUP BY URANIUM SPECIMENS TREATED(a) IN DIFFERENT SALT MIXES WHICH WERE AGED FOR 5 TO 7 DAYS UNDER WET AND DRY ATMOSPHERES

\begin{tabular}{|c|c|c|c|}
\hline \multirow[b]{2}{*}{ Salt Mix } & \multirow[b]{2}{*}{ Composition, w/o } & \multicolumn{2}{|c|}{ Hydrogen Pickup, ppm } \\
\hline & & $\begin{array}{c}\text { Dry } \\
\text { Atmosphere (b) }\end{array}$ & $\begin{array}{c}\text { Wet } \\
\text { Atmosphere (c) }\end{array}$ \\
\hline 4 & $44 \mathrm{Li}_{2} \mathrm{CO}_{3}-56 \mathrm{~K}_{2} \mathrm{CO}_{3}$ & $\begin{array}{l}5.5 \\
7.0(d) \\
11.9(e)\end{array}$ & $\begin{array}{c}13.3 \\
-- \\
12.3(\mathrm{e})\end{array}$ \\
\hline 20 & $25 \mathrm{Li}_{2} \mathrm{CO}_{3}-75 \mathrm{~K}_{2} \mathrm{CO}_{3}$ & 5.0 & 13.3 \\
\hline 21 & $15 \mathrm{Li}_{2} \mathrm{CO}_{3}-37 \mathrm{~K}_{2} \mathrm{CO}_{3}-48 \mathrm{Na}_{2} \mathrm{CO}_{3}$ & 6.6 & 12.1 \\
\hline 5 & $50 \mathrm{KCl}-50 \mathrm{Na}_{2} \mathrm{CO}_{3}$ & $\begin{array}{l}2.7 \\
1.5\end{array}$ & $\begin{array}{r}4.4 \\
--\end{array}$ \\
\hline 17 & $33 \mathrm{NaCl}-33 \mathrm{Na}_{2} \mathrm{CO}_{3}-33 \mathrm{KCl}$ & $\begin{array}{l}1.9 \\
3.3(e)\end{array}$ & $\begin{array}{r}4.0 \\
--\end{array}$ \\
\hline 9 & $50 \mathrm{KCl}-50 \mathrm{NaCl}$ & $\begin{array}{l}5.5 \\
2.6(\mathrm{~d}) \\
1.0(\mathrm{e})\end{array}$ & $\begin{array}{l}7.7 \\
7.4(\mathrm{~d}) \\
2.8(\mathrm{e})\end{array}$ \\
\hline 14 & $25 \mathrm{LiCl}-25 \mathrm{NaCl}-50 \mathrm{KCl}$ & $\begin{array}{l}7.6 \\
8.4(d) \\
9.8(e)\end{array}$ & $\begin{array}{l}5.8 \\
3.7(\dot{d}) \\
--\end{array}$ \\
\hline
\end{tabular}

(a) Uranium specimens treated for 1 hour at $1350 \mathrm{~F}$ and quenched in water. Salt mix contained in platinum crucibles and uranium specimens placed directly in crucibles except where noted otherwise.

(b) Humidity was maintained at a partial pressure at $0.5 \mathrm{~mm}$ of mercury or less.

(c) Humidity was maintained at a partial pressure of $70 \mathrm{~mm}$ to $80 \mathrm{~mm}$ of mercury.

(d) Uranium specimens placed in a Vycor holder to prevent contact with platinum crucible. These figures include results obtained where atmosphere was maintained $\mathrm{CO}_{2}$-free, since the presence of $\mathrm{CO}_{2}$ had no significant influence on the hydrogen pickup.

(e) Salt mix contained in porcelain crucible.

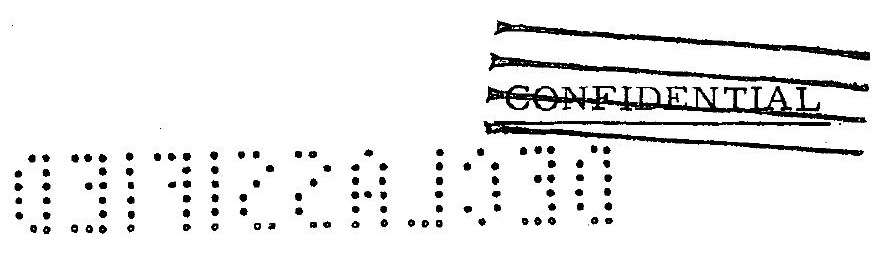




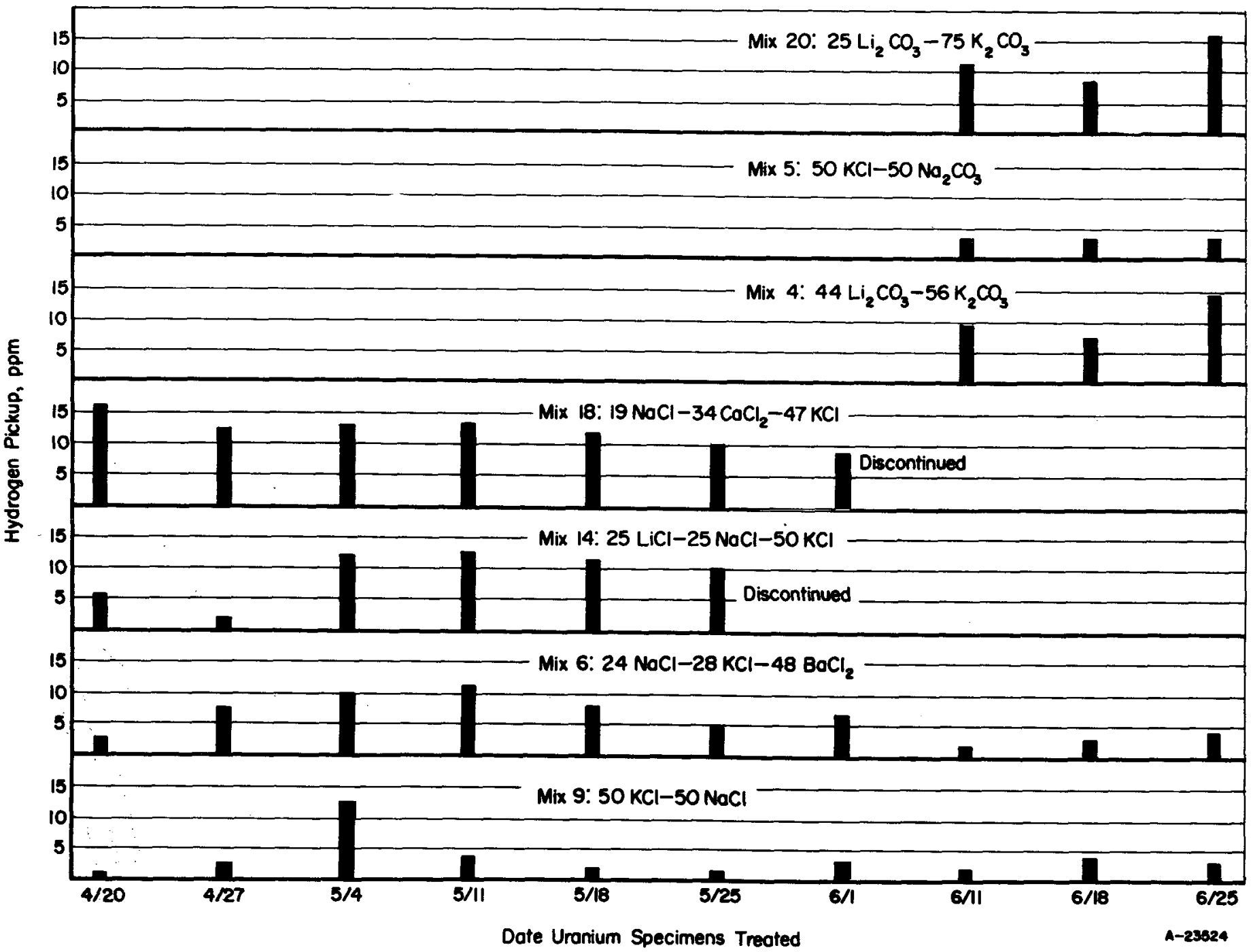

FIGURE 1. HYDROGEN PICKUP BY URANIUM SPECIMENS HEAT TREATED IN DIFFERENT SALT MIXES EXPOSED TO THE ROOM ATMOSPHERE

Salt baths operated continiuuusiy with uranium specimens treated at 7 -day intervals. Compositions are given in w/o. 
to cause excessive pitting of the uranium specimens. The test on Salt Mix 14 was discontinued because the hydrogen pickup was too great.

In summary, the following salt mixes showed some promise for reducing hydrogen pickup below that resulting from the use of $\mathrm{Li}_{2} \mathrm{CO}_{3}-\mathrm{K}_{2} \mathrm{CO}_{3}$ salt mixes:

$\begin{array}{ll}\operatorname{Mix} 9 & 50 \mathrm{w} / \circ \mathrm{KCl}-50 \mathrm{w} / \circ \mathrm{NaCl} \\ \operatorname{Mix} 5 & 50 \mathrm{w} / \circ \mathrm{KCl}-50 \mathrm{w} / \circ \mathrm{Na}_{2} \mathrm{CO}_{3} \\ \mathrm{Mix} 17 & 33 \mathrm{w} / \circ \mathrm{KCl}-33 \mathrm{w} / \circ \mathrm{NaCl}-33 \mathrm{w} / \circ \mathrm{Na}_{2} \mathrm{CO}_{3} \\ \mathrm{Mix} 6 & 24 \mathrm{w} / 0 \mathrm{NaCl}-28 \mathrm{w} / 0 \mathrm{KCl}-48 \mathrm{w} / 0 \mathrm{BaCl}_{2}\end{array}$

Of these, Salt Mix 6 can be eliminated, because it promotes excessive pitting of the uranium. Salt Mix 17 could be considered, but it is more complex and not significantly better than Salt Mix 5. Thus, Salt Mixes 9 and 5 emerge as the ones showing the most promise for future work.

The Dependence of Hydrogen Pickup on Humidity

The dependence of hydrogen pickup on humidity was not evident from the results obtained from the initial 2-day aging procedure (see Table 1). It was suspected that this lack of dependence of hydrogen pickup on humidity might have been caused by (1) the salt bath not coming to equilibrium with the atmosphere in only 2 days and (2) the porous walls of the muffle furnace allowing the composition of the atmosphere in the furnace to change by diffusion through the walls.

Hence, as already explained, the test procedure was modified by increasing the fused salt aging period to 5 to 7 days and by installing a nickel liner in the muffle furnace. To make the dependence of hydrogen pickup on atmospheric moisture more obvious, the partial pressure of the water vapor over the salt baths was increased to $70 \mathrm{~mm}$ of mercury. Except for Salt Mix 14, Table 2 shows that the hydrogen pickup depends on the humidity. The moderate increase in hydrogen pickup with increased moisture in the chloride-carbonate salt mixes and the $\mathrm{KCl}-\mathrm{NaCl}$ salt mix contained in porcelain crucibles makes these salt mixes look very promising because the wet atmosphere corresponds to the extreme condition of air at $115 \mathrm{~F}$ saturated with water vapor.

The Effect of Hydroxyl-Ion Concentration on Hydrogen Pickup

For a given salt mixture, a higher hydrogen pickup is attended by a greater hydroxyl-ion concentration. This holds for all baths except those composed only of chlorides. In the latter case this correlation is lacking.

Uranium-Specimen Corrosion

The uranium specimen treated in Salt Mix 8 (26.5 w/o $\left.\mathrm{K}_{2} \mathrm{SO}_{4}-73.5 \mathrm{Li}_{2} \mathrm{SO}_{4}\right)$ dissolved completely. This result obviously eliminates the use of sulfates as salt baths

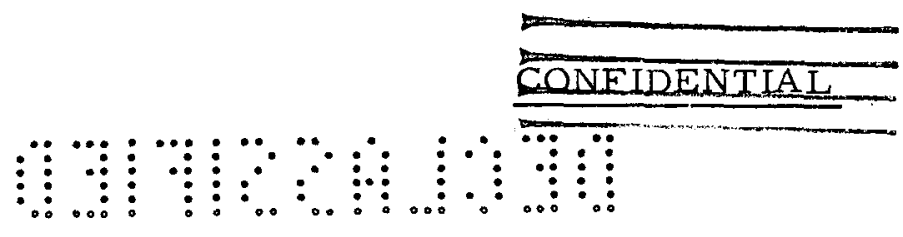




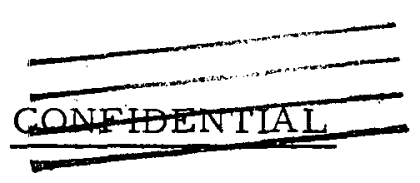

13

for heat treating uranium. The two salt mixes containing $\mathrm{BaCl}_{2}$ ( $\mathrm{Mix} 6,24 \mathrm{w} / \mathrm{o} \mathrm{NaCl-}$ $28 \mathrm{w} / \mathrm{o} \mathrm{KCl}-48 \mathrm{BaCl}_{2}$ and $\mathrm{Mix} \mathrm{13,} 21 \mathrm{w} / \mathrm{o} \mathrm{NaCl}-48 \mathrm{w} / \mathrm{o} \mathrm{CaCl} 2-31 \mathrm{BaCl}_{2}$ ) caused noticeable pitting on the surface of the uranium in the initial 2-day aging procedure.

Uranium tended to lose more weight when treated in a fused salt mix exposed to a wet atmosphere than when treated in a salt mix exposed to a dry atmosphere. In general, the uranium weight los $\mathrm{s}$ was considerably less in the $\mathrm{KCl}-\mathrm{NaCl}$ salt mix (less than 1 per cent) than in the all-carbonate or carbonate-chloride salt mixes ( 1 to 5 per cent). The addition of $\mathrm{KOH}$ to a salt mix increased the uranium weight los .

When platinum crucibles were used with the all-chloride salt mixes, the uranium weight losses were much greater (as high as 38 per cent in one case) than when porcelain crucibles were used (less than 1 per cent). The use of Vycor holders to prevent contact of the uranium and platinum generally reduced the uranium weight loss considerably below the weight loss ochurring with direct contact. The increased weight losses that occurred when the uranium was in direct contact with platinum in an allchloride fused salt $\mathrm{mix}$ indicate that an electrochemical attack or catalytic action was taking place. The lower weight loss obtained with the $\mathrm{KCl}-\mathrm{NaCl}$ salt $\mathrm{mix}$ (Mix 9) indicates that this salt mix has another advantage over the other salt mixes tested in addition to its potential value for minimizing hydrogen pickup.

\section{PART II. PILOT-PLANT SCALE EXPERIMENTAL WORK}

Description of Procedure

Uranium specimens were heat treated at weekly intervals in five different salt baths. Each salt bath was aged for 3 weeks. Two of the five salt baths consisted primarily of $50 \mathrm{w} / 0 \mathrm{KCl}-50 \mathrm{w} / \mathrm{O} \mathrm{Na}_{2} \mathrm{CO}_{3}$, while the other three salt baths consisted. primarily of $50 \mathrm{w} / 0 \mathrm{KCl}-50 \mathrm{w} / 0 \mathrm{NaCl}$. * Each of the five salt baths contained apprcximately $6.5 \mathrm{w} / \mathrm{o}$ of salts such as might be carried over from the alpha equilizer into the beta salt bath in a commercial plant. The treated uranium specimens were sent to NLO at Fernald, Ohio, for hydrogen analysis.

The uranium specimens used in this work were obtained from NLO. These specimens were sections approximately 2 in. long that had been cut from 1,5-in. rods and outgassed. Ten uranium specimens were chosen at random and analyzed prior to heat treating for hydrogen content to establish the average initial hydrogen content and the standard deviation of initial hydrogen content." Two uranium specimens were selected at random for heat treating each week, weighed, immersed in the salt bath at $1350 \mathrm{~F}$ for $13.5 \mathrm{~min}$, removed, quenched in water for $2 \mathrm{~min}$, immersed in a second tank of: water for $10 \mathrm{sec}$, allowed to dry, and reweighed. A few of the specimens were rinsed a second time in approximately $140 \mathrm{ml}$ of deionized water to obtain a rinse sample for chloride analysis. Some of the uranium specimens were leached with nitric acid by NLO to determine the chloride content on the outer layer of these uranium specimens. Two additional specimens were treated for 135 min in Salt Bath 3 at the end of the tinird

\footnotetext{
- These salt mixtures were supplied for the experimental work by Park Chemical Company.
}

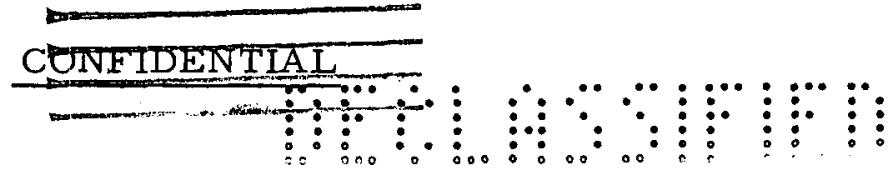




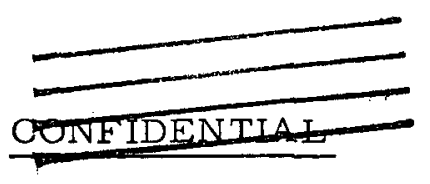

14

week of operation, and two additional specimens were treated for $6.75 \mathrm{~min}$ in Salt Bath 4 at the end of the third week of operation.

Relative humidity and room temperature were recorded near the salt-bath furnace continuously during runs in Salt Baths 2 through 5. In general, samples of the salt baths were taken before and after treating the uranium specimens.

The salt baths were made up in approximately 100-1b batches for melting in the furnace; smaller batches were made up to adjust and maintain the salt-bath level throughout the 3 weeks of operation. The five salt-bath compositions are listed below.

\begin{tabular}{|c|c|}
\hline Salt Bath 1 & $\begin{array}{l}93.5 \mathrm{w} / 0(50 \mathrm{KCl}-50 \mathrm{NaCl}) \\
6.5 \mathrm{w} / \mathrm{o}\left(50 \mathrm{KCl}-50 \mathrm{Na}_{2} \mathrm{CO}_{3}\right)\end{array}$ \\
\hline Salt Bath 2 & $\begin{array}{l}93.1 \mathrm{w} / \mathrm{o}\left(50 \mathrm{KCl}-50 \mathrm{Na}_{2} \mathrm{CO}_{3}\right) \\
6.9 \mathrm{w} / \mathrm{o}\left(44 \mathrm{Li}_{2} \mathrm{CO}_{3}-56 \mathrm{~K}_{2} \mathrm{CO}_{3}\right)\end{array}$ \\
\hline Salt Bath 3 & $\begin{array}{l}93.5 \mathrm{w} / \mathrm{o}\left(50 \mathrm{KCl}-50 \mathrm{Na}_{2} \mathrm{CO}_{3}\right) \\
6.5 \mathrm{w} / \mathrm{o}\left(25 \mathrm{Li}_{2} \mathrm{CO}_{3}-75 \mathrm{~K}_{2} \mathrm{CO}_{3}\right)\end{array}$ \\
\hline Salt Bath 4 & $\begin{array}{l}93.5 \mathrm{w} / \mathrm{o}(50 \mathrm{KCl}-50 \mathrm{NaCl}) \\
6.5 \mathrm{w} / \mathrm{o}\left(44 \mathrm{Li}_{2} \mathrm{CO}_{3}-56 \mathrm{~K}_{2} \mathrm{CO}_{3}\right)\end{array}$ \\
\hline Salt Bath 5 & $\begin{array}{l}93.5 \mathrm{w} / \mathrm{o}(50 \mathrm{KCl}-50 \mathrm{NaCl}) \\
6.5 \mathrm{w} / \mathrm{o}\left(25 \mathrm{Li}_{2} \mathrm{CO}_{3}-75 \mathrm{~K}_{2} \mathrm{CO}_{3}\right)\end{array}$ \\
\hline
\end{tabular}

Each salt bath was melted in the furnace and maintained at $1350 \mathrm{~F}$ for 3 weeks. Uranium specimens were treated at the end of each week of operation. Corrosion specimens 6 in. long were suspended in each salt bath with approximately 2 in. of each specimen below the salt-bath level. Mild steel and Types 304, 330, 416, and 446 stainless steel were used as corrosion specimens. The corrosion specimens were sectioned so that areas below and above the salt bath level could be examined. Depth of corrosion, depth of intergranular penetration, and crystal-structure change were determined by metallographic examination.

An Ajax Electric Company electric salt-bath furnace was used for the experiments described. Welded cylindrical pots made from 3/8-in. mild steel (12-in. internal diameter and 20-in. depth) were used to contain the molten salt. Two-in.-square mildsteel electrodes were used to heat the molten salt; these electrodes extended approximately $15 \mathrm{in}$. below the salt-bath level. The temperature was controlled at $1350 \mathrm{~F}$ with a platinum versus platinum-rhodium thermocouple; a Ray-O-Tube was employed as a "fail-safe" device.

Experimental Results

The results show that the hydrogen pickup in $50 \mathrm{w} / \mathrm{o} \mathrm{KCl}-50 \mathrm{w} / \mathrm{o} \mathrm{NaCl}$ salt baths was lower than in the $50 \mathrm{w} / 0 \mathrm{KCl}-50 \mathrm{w} / 0 \mathrm{Na}_{2} \mathrm{CO}_{3}$ salt baths. Neither the greater $\mathrm{Li}_{2} \mathrm{CO}_{3}$ contents nor the age of the salt bath seemed to result in increased hydrogen pickup. It is possible that any effect of $\mathrm{Li}_{2} \mathrm{CO}_{3}$ content or bath age may have been

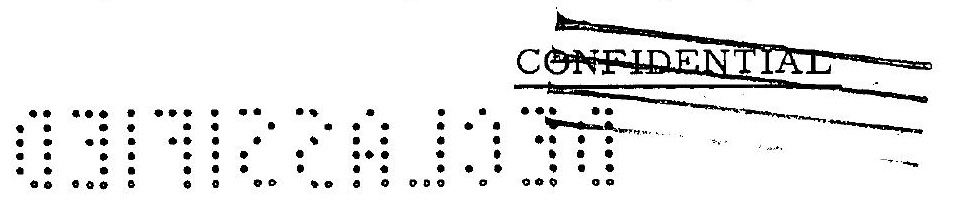


obscured by the influence of humidity upon the hydrogen pickup. Hydrogen pickup did tend to vary directly with the humidity recorded at the instant of heat treating; however, the large variance of hydrogen content that existed in the uranium specimens before heat treating precluded any quantitative verification. For the same reason, the alkalinity for a given salt bath could not be correlated with hydrogen pickup.

Dependence of Hydrogen Pickup on Type of Salt Bath

Average hydrogen contents for the pair of uranium specimens treated each week in each of the five salt baths are shown in Table 3 (individual results are recorded in Appendix B, Table B-1). Variance analysis of the individual hydrogen contents for the 18 uranium specimens treated in the $50 \mathrm{w} / \mathrm{o} \mathrm{KCl}-50 \mathrm{w} / \mathrm{o} \mathrm{NaCl}$ salt baths and the 12 uranium specimens treated in the $50 \mathrm{w} / 0 \mathrm{KCl}-50 \mathrm{w} / 0 \mathrm{Na}_{2} \mathrm{CO}_{3}$ salt baths shows that the average hydrogen content of uranium specimens treated in the $50 \mathrm{w} / \mathrm{o} \mathrm{KCl}-50 \mathrm{w} / \mathrm{o}$ $\mathrm{Na}_{2} \mathrm{CO}_{3}$ salt baths was greater than the average hydrogen content of the uranium specimens treated in the $50 \mathrm{w} / 0 \mathrm{KCl}-50 \mathrm{w} / 0 \mathrm{NaCl}$ salt bath.

TABLE 3. AVERAGE FINAL HYDROGEN CONTENT OF EACH PAIR OF URANIUM SPECIMENS TREATED(a) IN SALT BATHS

\begin{tabular}{ccccc}
\hline & \multicolumn{2}{c}{$\begin{array}{c}\text { Hydrogen Content, ppm, of Specimens } \\
\text { Treated at End of Week Indicated }\end{array}$} & \\
\cline { 2 - 5 } Salt Bath (b) & First Week & Second Week & Third Week & Over-All Average \\
\hline 1 & 0.36 & 0.39 & 0.49 & 0.41 \\
2 & 0.91 & 1.03 & 0.66 & 0.87 \\
3 & 0.80 & 0.74 & 0.50 & 0.67 \\
4 & 0.50 & 0.43 & 0.27 & 0.40 \\
5 & 0.54 & 0.59 & 0.68 & 0.60 \\
\hline
\end{tabular}

(a) Treatment consisted of immersing specimens in salt bath at $1350 \mathrm{~F}$ for $13.5 \mathrm{~min}$, quenching in water for $2 \mathrm{~min}$, and rinsing in second tank of water for $10 \mathrm{sec}$.

(b) Salt Baths 1, 4, and 5 consist primarily of $50 \mathrm{w} / \mathrm{o} \mathrm{NaCl}-50 \mathrm{w} / \mathrm{o} \mathrm{KCl}$. Salt Baths 2 and 3 consist primarily of $50 \mathrm{w} / \mathrm{o} \mathrm{KCl}-50 \mathrm{w} / \mathrm{o} \mathrm{Na}{ }_{2} \mathrm{CO}_{3}$.

Analysis of ten uranium specimens taken at random from the batch of specimens available for these tests showed an average hydrogen content of $0.27 \mathrm{ppm}$, with individual results varying from 0.15 to $0.58 \mathrm{ppm}$ (Appendix Table B-3). The large variations in initial hydrogen content explain the large hydrogen-content differences obtained after treatment of duplicate specimens (see Figure 2). Subtraction of this average initial hydrogen content from the average final hydrogen contents gave an estimated average hydrogen pickup of $0.14,0.60,0.41,0.17$, and $0.33 \mathrm{ppm}$ for ruis in Salt Baths 1 through 5, respectively. These estimated average hydrogen-pickup figures for each salt bath indicate that both the $50 \mathrm{w} / \mathrm{OKCl}-50 \mathrm{w} / \mathrm{O} \mathrm{NaCl}$ and the $50 \mathrm{~N} / \mathrm{O}$ $\mathrm{KCl}-50 \mathrm{w} / \mathrm{O} \mathrm{Na}_{2} \mathrm{CO}_{3}$ salt baths gave much lower hydrogen pickup than the salt bath operating at Fernald, Ohio.

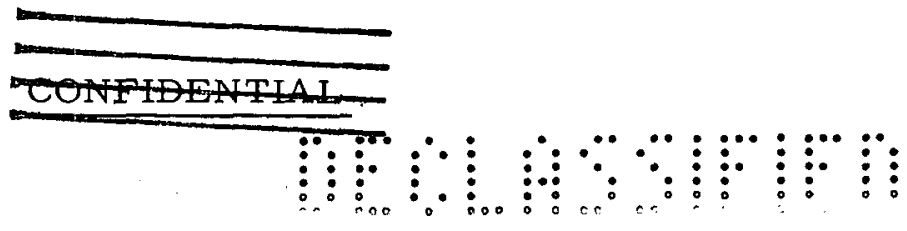


$\therefore . . .$.

$\therefore$

......

....: :

......

$\because \because \because$

$\because " \because$

•

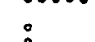

$\vdots \ldots$

$\therefore . .$.
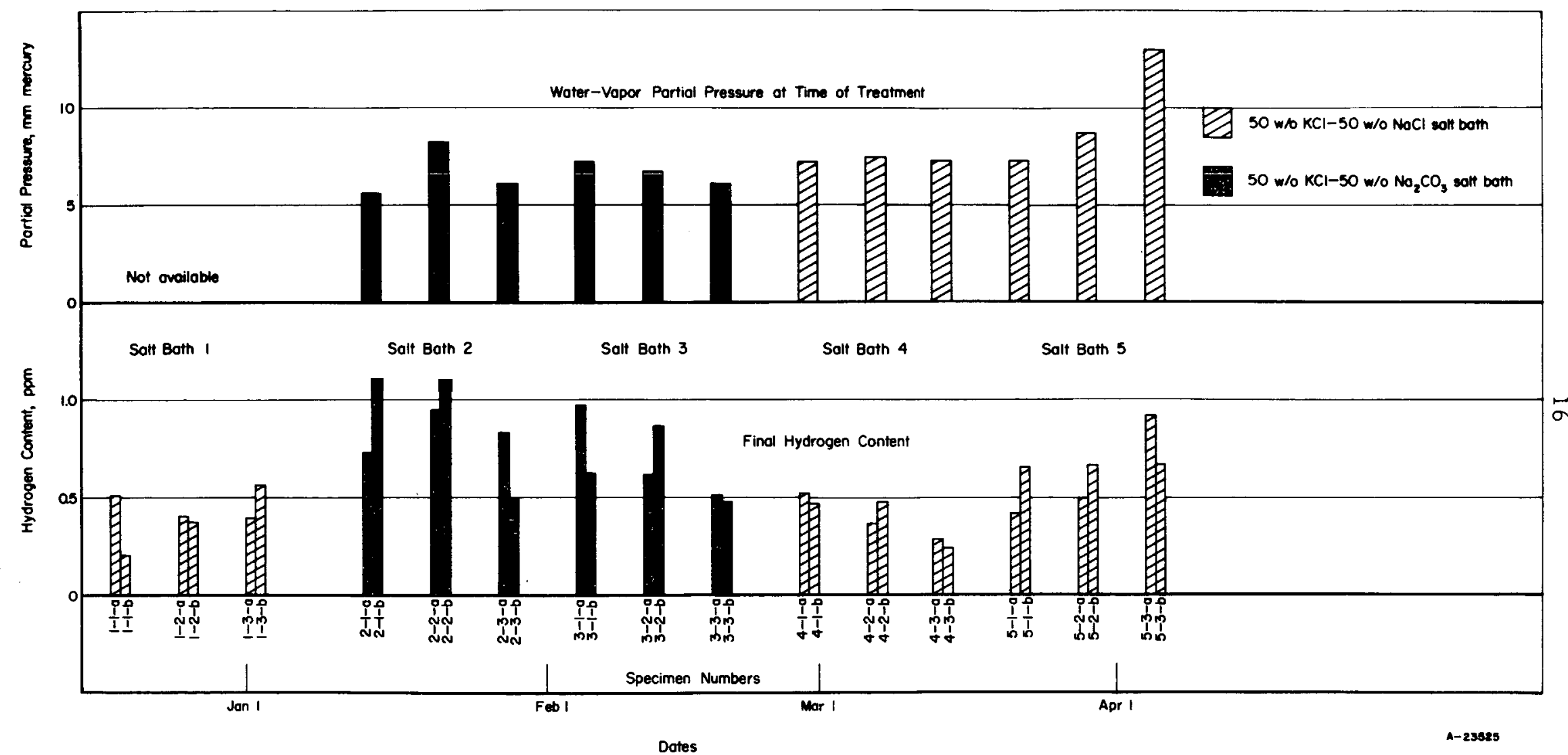

FIGURE 2. HYDROGEN PICKUP OF INDIVIDUAL URANIUM SPECIMENS AND HUMIDITY AT TIME OF EXPOSURE 


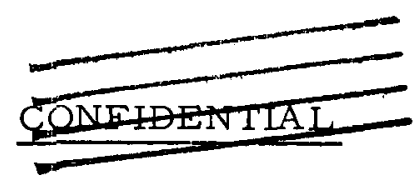

17

Hydrogen Pickup Compared With the Effect of Humidity, Salt-Bath Age, Type of Contaminant, and Salt-Bath Alkalinity on Hydrogen Pickup

Figure 2 shows final hydrogen content and the water-vapor partial pressures in the atmosphere above the salt bath at the time the uranium specimens were treated. The results indicate possible correlation between the water-vapor partial pressure over the salt during treatment and the hydrogen pickup in all runs except that in Salt Bath 4. Humidity data are not available for the period of the run in Salt Bath 1 . If the age or the $\mathrm{Li}_{2} \mathrm{CO}_{3}$ content of the salt bath influences the hydrogen pickup by the uranium specimens, any such correlation is obscured by the influence of humidity and the large variation in initial hydrogen contents of the uranium specimens. The average humidity over the salt bath for the week immediately preceding treatment (Appendis: $B$, Table B-1) showed no apparent correlation with hydrogen pickup.

The salt-bath hydroxyl-ion concentration was definitely lower in the $50 \mathrm{w} / \mathrm{O}$ $\mathrm{KCl}-50 \mathrm{w} / \mathrm{o} \mathrm{NaCl}$ salt baths $(0.04$ to 0.21 per cent) than in the $50 \mathrm{w} / \mathrm{o} \mathrm{KCl}-50 \mathrm{w} / \mathrm{o}$ $\mathrm{Na}_{2} \mathrm{CO}_{3}$ salt baths (0.29 to 0.35 per cent). Salt Bath 1 , which contained no $\mathrm{Li}_{2} \mathrm{CO}_{3}$ $\left(50 \mathrm{w} / 0 \mathrm{KCl}-50 \mathrm{w} / \mathrm{o} \mathrm{Na}_{2} \mathrm{CO}_{3}\right.$ was used as the contaminant), had very low hydroxyl-ion contents (0.04 to 0.08 per cent). However, for a given salt bath the re were not sufficient data to establish an exact relationship between hydroxyl content and the hydrogen pickup by individual uranium specimens. There was no significant variation apparent between the hydroxyl-ion content before and after heat treating.

Adherence of Salt to Uranium Following Quench

No salt could be seen on the uranium specimens after the 2 -min quench. Thus it does not appear likely that any substantial quantities of chloride could be carried over to the machining operations. To determine whether or not there was any significant amount of chloride ion adhering to the uranium specimen after the usual quenching and rinsing step, the specimens were rinsed in approximately $140 \mathrm{ml}$ of deionized water which was then analyzed for chloride. The results (Table 4) show that the largest chloride pickup by a rinse sample was only $0.0007 \mathrm{~g}$. This corresponds to only $0.000061 \mathrm{~g}$ per in. 2 or $0.049 \mathrm{~g}$ per $15-\mathrm{ft}$ rod of uranium. NLO leached four uranium specimens with nitric acid (Table 5) and determined the chloride content ir. the leach. These specimens had not been given the special rinse for chloride determination at Battelle; thus, chloride that could have been rinsed off with water is included in these results. In the case of Specimens 5-3-a and 5-3-b the chloride found by the nitric acid leach was about the same as the largest result obtained from the water-rinse analysis. However, Specimens 5-1-a and 5-1-b showed considerably rnore chloride by the nitric acid-leach analysis, 0.0021 and $0.0027 \mathrm{~g}$, which corresponds to approximately 0.14 and $0.18 \mathrm{~g}$ per rod. These preliminary results do not represent a thorough study of chloride adherence and should not be used to predict chloride buildup in the machining stages. They do point up the need for some additional study to determine more accurately the probable chloride adherence and whether or not this amount of chloride adherence might cause problems in subsequent machining operations.

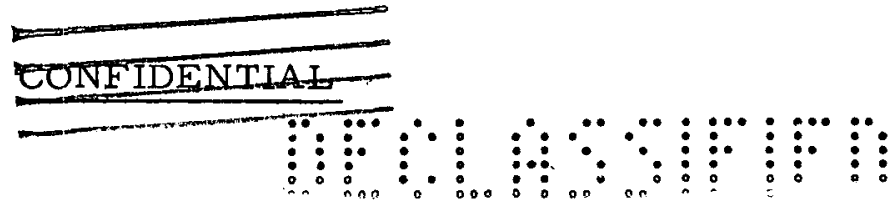




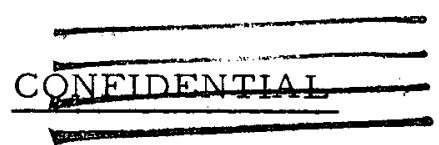

18

TABLE 4. AMOUNT OF CHLORIDE ION PICKED UP FROM URANIUM SPECIMENS BY WATER-RINSE SAMPLE(a)

\begin{tabular}{lc}
\hline \hline Specimen & Chloride, g \\
\hline $3-2-\mathrm{a}$ & $<0.0004$ \\
$3-2-\mathrm{b}$ & $<0.0004$ \\
$3-3-\mathrm{a}$ & 0.0004 \\
$3-3-\mathrm{b}$ & 0.0002 \\
$4-1-\mathrm{a}$ & $<0.0005$ \\
$4-1-\mathrm{b}$ & $<0.0005$ \\
$4-2-\mathrm{a}$ & 0.0007 \\
$4-2-\mathrm{b}$ & 0.0005 \\
\hline
\end{tabular}

(a) Uranium specimens rinsed in $140 \mathrm{ml}$ of deionized water after usual treatment (heat treat for $13.5 \mathrm{~min}$, quench in water for $2 \mathrm{~min}$, and rinse in water for $10 \mathrm{sec}$ ).

TABLE 5. AMOUNT OF CHLORIDE ION LEACHED(a) FROM URANIUM SPECIMENS BY NITRIC ACID

\begin{tabular}{lc}
\hline \hline Specimen & Chloride, g \\
\hline $5-1-\mathrm{a}$ & 0.0021 \\
$5-1-\mathrm{b}$ & 0.0027 \\
$5-3-\mathrm{a}$ & 0.0009 \\
$5-3-\mathrm{b}$ & 0.0010 \\
\hline
\end{tabular}

(a) NLO leached uranium specimens in nitric acid so that approximately $1 \mathrm{~g}$ of the uranium specimen was dissolved.

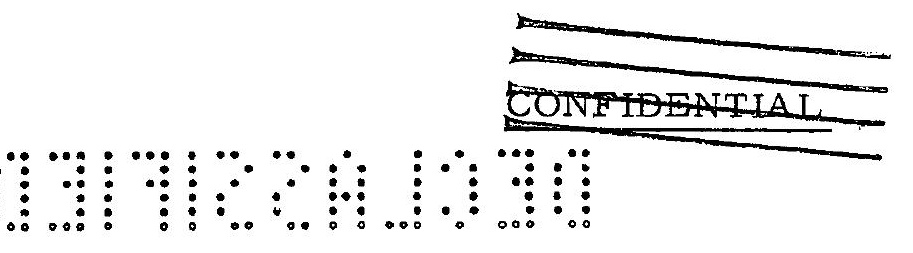


Preliminary Study of Materials Corrosion

Type 330 stainless steel resisted the attack of both the $\mathrm{KCl}-\mathrm{NaCl}$ and the $\mathrm{KCl}$ $\mathrm{Na}_{2} \mathrm{CO}_{3}$ salt baths better than did stainless steel Types 304,416 , and 446 or mild steel. Figure 3 shows the maximum corrosion observed in each type of salt bath with each type of metal except the Type 446 stainless steel, which corroded completely. Data for individual specimens are recorded in Appendix B, Table B-2.

Each particular type of metal showed about the same degree of corrosion in salt baths consisting of the same primary salts. In the case of Type 330 stainless steel, corrosion was generally uniform over the exposed surface. Both mild steel and Type 304 stainless steel showed severe pitting attack in the $\mathrm{KCl}-\mathrm{Na}_{2} \mathrm{CO}_{3}$ salt baths. Evidence of intergranular penetration was observed in the Types 304 and 416 stainless steel specimens. The Type 446 stainless steel specimens definitely corroded more than the Type 330 stainless steel, and selective penetration and pitting occurred in addition to metal removal. Corrosion of Type 446 stainless steel could not be determined quantitatively because that part of the specimens (1/4-in. tubes with $0.031-$ in. walls) ex-. posed to the salt bath were completely destroyed. In general, phase changes, decarburization, and perhaps some carburization occurred. However, the extent to which the operating temperature and the salt bath composition each contributed to these phenomena could not be determined from these preliminary corrosion studies.

Type 330 stainless steel corroded 0.002 in. in a 3 -week period in a $\mathrm{KCl}-\mathrm{NaCl}$ salt bath. At this rate, the yearly corrosion would be $0.04 \mathrm{in.} \mathrm{By} \mathrm{comparison,} \mathrm{the}$ yearly corrosion of mild steel would be $0.5 \mathrm{in}$. and the yearly corrosion of Type 304 stainless steel would be 0.24 in. However, a preliminary study of the effect of time on the corrosion of Type 304 stainless steel in a $\mathrm{KCl}-\mathrm{NaCl}$ salt bath indicated that the rate of corrosion might decrease with time. It is not known whether Type 330 stainless steel and the other materials tested would show a similar reduction in the rate of corrosion with time. Such factors as applied and residual stresses and changes in the oxygen content of the salt bath caused by aging and rectification, may differ considerably in the full-scale salt bath and must be considered in predicting probable rates of corrosion. Some of the conditions prevailing in the plant may even cause an increase in the corrosion rate with time with some of the materials.

LLL:KAS:RBF/apo 


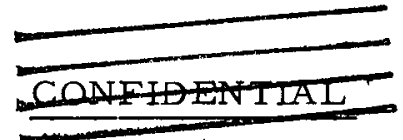

20

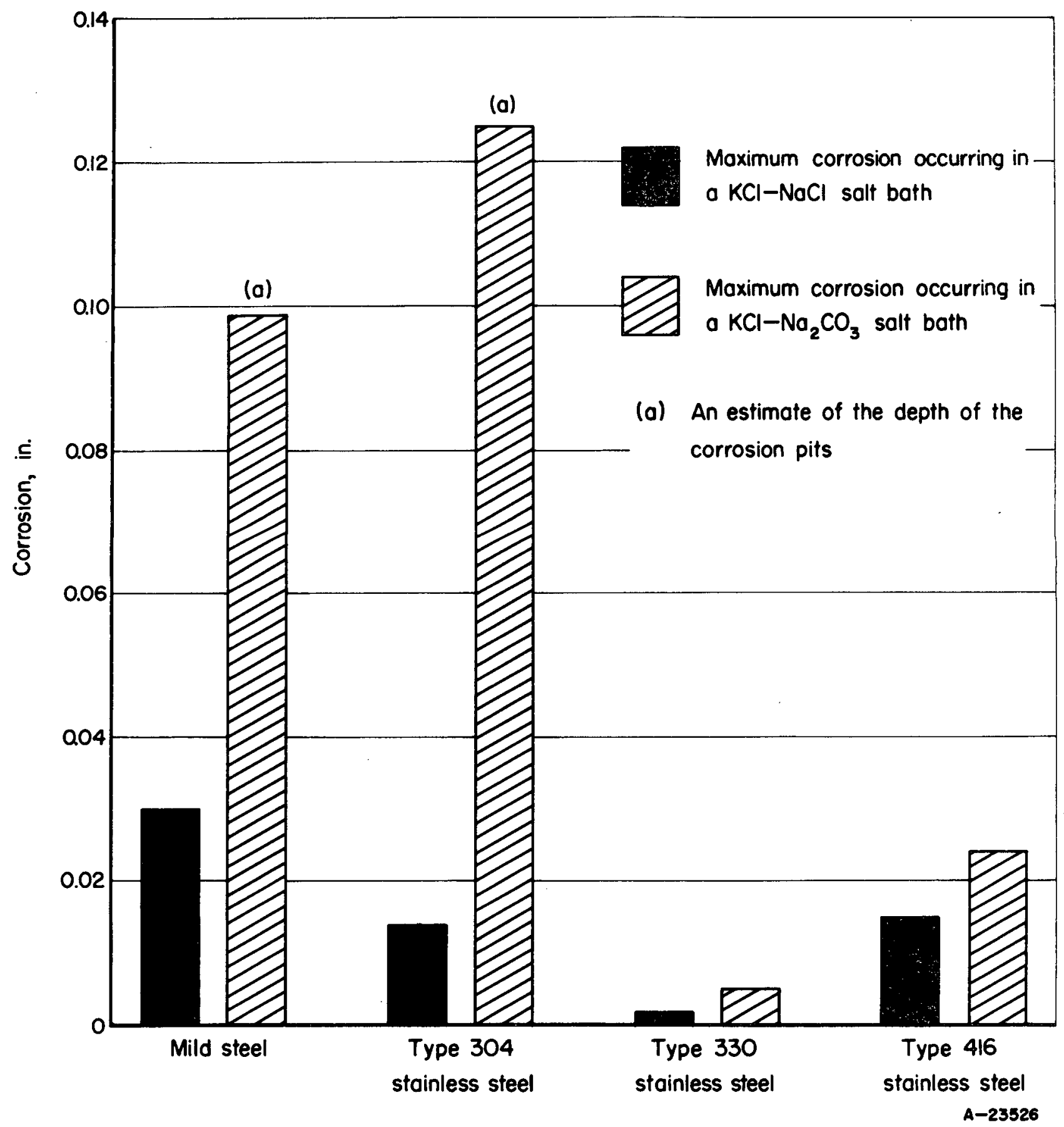

FIGURE 3. MAXIMUM CORROSION OF VARIOUS STEELS IN $\mathrm{KCl}-\mathrm{NaCl}$ AND $\mathrm{KCl}-\mathrm{Na}_{2} \mathrm{CO}_{3}$ SALT BATHS

Specimens partially immersed in salt baths at $1350 \mathrm{~F}$ for 3-week periods.

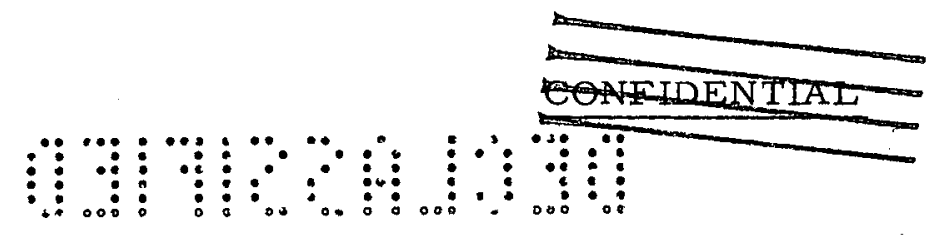




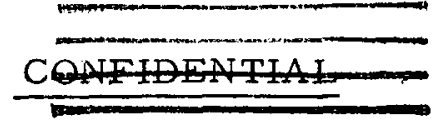

APPENDIX A

DATA FOR PART I 


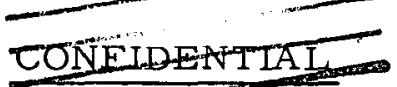

A- 1

TABLE A-1. COMPOSITION OF SALT MIXES INVESTIGATED IN LABORATORY WORK

\begin{tabular}{|c|c|}
\hline Salt Mix & Composition, w/o \\
\hline $1(a)$ & $44 \mathrm{NaCl}-56 \mathrm{MgCl}_{2}$ \\
\hline $2(a)$ & 17. $6 \mathrm{NaCl}-82.4 \mathrm{CuCl}$ \\
\hline 3 & $44 \mathrm{Li}_{2} \mathrm{CO}_{3}-56 \mathrm{Na}_{2} \mathrm{CO}_{3}$ \\
\hline 4 & $44 \mathrm{Li}_{2} \mathrm{CO}_{3}-56 \mathrm{~K}_{2} \mathrm{CO}_{3}$ \\
\hline 5 & $50 \mathrm{KCl}-50 \mathrm{Na}_{2} \mathrm{CO}_{3}$ \\
\hline 6 & $24 \mathrm{NaCl}-28 \mathrm{KCl}-48 \mathrm{BaCl}_{2}$ \\
\hline 7 & $22.5 \mathrm{NaBr}-77.5 \mathrm{LiBr}$ \\
\hline 8 & $26.5 \mathrm{~K}_{2} \mathrm{SO}_{4}-73.5 \mathrm{Li}_{2} \mathrm{SO}_{4}$ \\
\hline 9 & $50 \mathrm{KCl}-50 \mathrm{NaCl}$ \\
\hline 10 & 46. $2 \mathrm{LiCl}-53.8 \mathrm{KCl}$ \\
\hline 11 & 32. $8 \mathrm{NaCl}-67.2 \mathrm{CaCl}_{2}$ \\
\hline $12^{(a)}$ & $38.4 \mathrm{LiCl}-61.6 \mathrm{CaCl}_{2}$ \\
\hline 13 & $21 \mathrm{NaCl}-31 \mathrm{BaCl}_{2}-48 \mathrm{CaCl}_{2}$ \\
\hline 14 & $25 \mathrm{NaCl}-25 \mathrm{LiCl}-50 \mathrm{KCl}$ \\
\hline 15 & $30 \mathrm{LiCl}-70 \mathrm{KCl}$ \\
\hline 17 & $33 \mathrm{NaCl}-33 \mathrm{KCl}-33 \mathrm{Na}_{2} \mathrm{CO}_{3}$ \\
\hline 18 & $19 \mathrm{NaCl}-34 \mathrm{CaCl}_{2}-47 \mathrm{KCl}$ \\
\hline 20 & $25 \mathrm{Li}_{2} \mathrm{CO}_{3}-75 \mathrm{~K}_{2} \mathrm{CO}_{3}$ \\
\hline 21 & $15 \mathrm{Li}_{2} \mathrm{CO}_{3}-37 \mathrm{~K}_{2} \mathrm{CO}_{3}-48 \mathrm{Na}_{2} \mathrm{CO}_{3}$ \\
\hline 22 & $50 \mathrm{Na}_{2} \mathrm{CO}_{3}-50 \mathrm{~K}_{2} \mathrm{CO}_{3}$ \\
\hline
\end{tabular}

(a) These salt mixes were eliminated on the basis of adverse thermodynamic or physical properties prior to immersion of uranium.

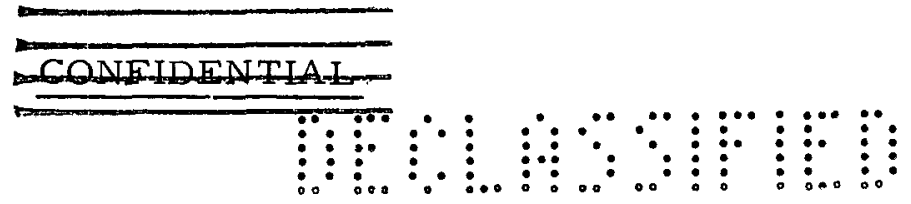


TABLE A-2. RESULTS AND CONDITIONS OF LABORATORY TESTS

\begin{tabular}{|c|c|c|c|c|c|c|c|c|c|c|c|c|c|}
\hline \multirow[b]{2}{*}{ Run } & \multirow[b]{2}{*}{$\begin{array}{l}\text { Uranium } \\
\text { Specimen }\end{array}$} & \multirow[b]{2}{*}{$\begin{array}{l}\text { Salt } \\
\text { Mix }\end{array}$} & \multirow[b]{2}{*}{$\begin{array}{c}\text { Composition of } \\
\text { Salt Mix } \\
w / 0\end{array}$} & \multirow[b]{2}{*}{$\begin{array}{c}\text { Hydrogen } \\
\text { Pickup, } \\
\text { ppm }\end{array}$} & \multirow[b]{2}{*}{$\begin{array}{l}\text { Weight } \\
\text { Loss, } \\
\text { per cent }\end{array}$} & \multirow[b]{2}{*}{$\begin{array}{c}\text { Weight } \\
\text { Loss, } \\
\text { B }\end{array}$} & \multicolumn{2}{|c|}{$\begin{array}{c}\text { Partial } \\
\text { Vapor Pressure } \\
\text { of Water, } \\
\text { mm mercury } \\
\end{array}$} & \multicolumn{2}{|c|}{$\begin{array}{c}\text { Free Hydroxyl ton, } \\
\text { per cent }\end{array}$} & \multirow[b]{2}{*}{$\begin{array}{c}\text { Aging } \\
\text { Period, } \\
\text { days }\end{array}$} & \multirow[b]{2}{*}{$\begin{array}{c}\text { Type } \\
\text { of } \\
\text { Crucible } \\
\text { (a) }\end{array}$} & \multirow[b]{2}{*}{ Notes } \\
\hline & & & & & & & $\begin{array}{l}\text { At Time } \\
\text { Uranium } \\
\text { Treated }\end{array}$ & $\begin{array}{c}\text { For } \\
\text { Aging } \\
\text { Period } \\
\end{array}$ & $\begin{array}{c}\text { Before } \\
\text { Uranium } \\
\text { Treated }\end{array}$ & $\begin{array}{l}\text { After } \\
\text { Uranium } \\
\text { Treated }\end{array}$ & & & \\
\hline \multirow[t]{7}{*}{1} & 1 & 5 & $50 \mathrm{KCl}-50 \mathrm{Na}_{2} \mathrm{CO}_{3}$ & 3.2 & 2.9 & 0.2112 & 18 & 18 & 0.44 & - & 2 & Po & - \\
\hline & 2 & 6 & $24 \mathrm{NaCl}-28 \mathrm{KCl}-48 \mathrm{BaCl}_{2}$ & 1.5 & 2.6 & 0.1862 & 18 & 18 & - & - & 2 & Po & - \\
\hline & 3 & 3 & $44 \mathrm{Li}_{2} \mathrm{CO}_{3}-56 \mathrm{Na}_{2} \mathrm{CO}_{3}$ & 8.7 & 3.7 & 0.2728 & 18 & 18 & - & - & 2 & Ms & - \\
\hline & 4 & 8 & $26.5 \mathrm{~K}_{2} \mathrm{SO}_{4}-73.5 \mathrm{Li}_{2} \mathrm{SO}_{4}$ & - & 100.0 & Total & 18 & 18 & - & - & 2 & Po & Uranium completely reacted \\
\hline & 5 & 7 & $22.5 \mathrm{NaBr}-77.5 \mathrm{LiBr}$ & 2.4 & 2.8 & 0.1987 & 18 & 18 & - & - & 2 & Po & - \\
\hline & 6 & 4 & $44 \mathrm{Li}_{2} \mathrm{CO}_{3}-56 \mathrm{~K}_{2} \mathrm{CO}_{3}$ & 9.7 & 2.0 & 0.1458 & 18 & 18 & 1.00 & 1.33 & 2 & Po & - \\
\hline & 7 & 5 & $50 \mathrm{KCl}-50 \mathrm{Na}_{2} \mathrm{CO}_{3}$ & 4.1 & 3.4 & 0.2381 & 18 & 18 & 0.44 & 0.55 & 2 & $P_{0}$ & - \\
\hline \multirow[t]{6}{*}{2} & 8 & 4 & $44 \mathrm{Li}_{2} \mathrm{CO}_{3}-56 \mathrm{~K}_{2} \mathrm{CO}_{3}$ & 7.8 & 1.3 & 0.1061 & 15 & 15 & 0.92 & 1.11 & 2 & Po & - \\
\hline & 9 & 3 & $44 \mathrm{Li}_{2} \mathrm{CO}_{3}-56 \mathrm{Na}_{2} \mathrm{CO}_{3}$ & 7.7 & 3.6 & 0.2640 & 15 & 15 & - & - & 2 & Ms & - \\
\hline & 10 & 9 & $50 \mathrm{KCl}+50 \mathrm{NaCl}$ & 0.9 & 0.3 & 0.2240 & 15 & 15 & - & - & 2 & Po & - \\
\hline & 11 & 7 & $22.5 \mathrm{NaBr}-77.5 \mathrm{LiBr}$ & 1.9 & 3.3 & 0.2621 & 15 & 15 & - & - & 2 & $\mathrm{P}_{0}$ & - \\
\hline & 12 & 6 & $24 \mathrm{NaCl}-28 \mathrm{KCl}-48 \mathrm{BaCl}_{2}$ & 1.3 & 26.3 & 1.9639 & 15 & 15 & - & - & 2 & $\mathrm{Ag}_{\mathrm{B}}$ & - \\
\hline & 13 & 5 & $50 \mathrm{KCl}-50 \mathrm{Na}_{2} \mathrm{CO}_{3}$ & 3.7 & 3.0 & 0.2364 & 15 & 15 & 0.38 & 0.56 & 2 & Po & - \\
\hline \multirow[t]{7}{*}{3} & 14 & 9 & $50 \mathrm{KCl}-50 \mathrm{NaCl}$ & 1.0 & 0.2 & 0.0161 & 20 & 20 & - & - & 2 & Po & - \\
\hline & 15 & 3 & $44 \mathrm{Li}_{2} \mathrm{CO}_{3}-56 \mathrm{Na}_{2} \mathrm{CO}_{3}$ & 9.2 & 2.5 & 0.2039 & 20 & 20 & - & - & 2 & Ms & - \\
\hline & 16 & 10 & $46.2 \mathrm{LiCl}-53.8 \mathrm{KCl}$ & 4.2 & 1.1 & 0.0813 & 20 & 20 & 0.09 & 0.05 & 2 & Po & - \\
\hline & 17 & Air & - & - & 58.2 & 4.4721 & 20 & 20 & - & - & 2 & Po & Oxide left \\
\hline & 18 & 11 & $32.8 \mathrm{NaCl}-67.2 \mathrm{CaCl}_{2}$ & 4.7 & 1.0 & 0.0758 & 20 & 20 & - & - & 2 & Po & - \\
\hline & 19 & 5 & $50 \mathrm{KCl}-50 \mathrm{Na}_{2} \mathrm{CO}_{3}$ & 3.9 & 2.8 & 0.2207 & 20 & 20 & 0.30 & 0.33 & 2 & Po & - \\
\hline & 20 & 4 & $44 \mathrm{Li}_{2} \mathrm{CO}_{3}-56 \mathrm{~K}_{2} \mathrm{CO}_{3}$ & 9.1 & 1.4 & 0.1095 & 20 & 20 & 1.15 & 1.60 & 2 & Po & - \\
\hline \multirow[t]{6}{*}{4} & 21 & 10 & $46.2 \mathrm{LICl}-53.8 \mathrm{KCl}$ & 8.5 & 0.4 & 0.0277 & 10 & 10 & - & - & 2 & $p_{0}$ & - \\
\hline & 22 & 3 & $44 \mathrm{Li}_{2} \mathrm{CO}_{3}-56 \mathrm{~K}_{2} \mathrm{CO}_{3}$ & 6.2 & 3.8 & 0.2882 & 10 & 10 & - & - & 2 & Ms & - \\
\hline & 23 & 9 & $50 \mathrm{KCl}-50 \mathrm{NaCl}$ & 1.0 & 0.2 & 0.0131 & 10 & 10 & 0.02 & - & 2 & Po & - \\
\hline & 24 & 13 & $21 \mathrm{NaCl}^{-31 \mathrm{BaCl}_{2}-48 \mathrm{CaCl}_{2}}$ & 3.0 & 1.9 & 0.1510 & 10 & 10 & - & - & 2 & Po & - \\
\hline & 25 & 5 & $50 \mathrm{KCl}-50 \mathrm{Na}_{2} \mathrm{CO}_{3}$ & 3.9 & 3.4 & 0.2591 & 10 & 10 & 0.51 & 0.66 & 2 & Po & - \\
\hline & 26 & 4 & $44 \mathrm{Li}_{2} \mathrm{CO}_{3}-56 \mathrm{~K}_{2} \mathrm{CO}_{3}$ & 10.6 & 1.9 & 0.1448 & 10 & 10 & 0.88 & 1.42 & 2 & $\mathrm{Po}$ & - \\
\hline \multirow[t]{6}{*}{5} & 27 & 4 & $44 \mathrm{Li}_{2} \mathrm{CO}_{3}-56 \mathrm{~K}_{2} \mathrm{CO}_{3}$ & 8.6 & 1.6 & 0.1218 & 30 & 30 & - & - & 2 & Po & - \\
\hline & 28 & 15 & 30 LiCl-70 KCl & 9.6 & 0.3 & 0.0218 & 30 & 30 & - & - & 2 & Po & - \\
\hline & 29 & 10 & $46.2 \mathrm{LICl}-53.8 \mathrm{KCl}$ & 6.5 & 1.0 & 0.0782 & 30 & 30 & - & - & 2 & Po & - \\
\hline & 30 & 14 & $25 \mathrm{NaCl}-25 \mathrm{LiCl}-50 \mathrm{KCl}$ & 9.5 & 0.4 & 0.0274 & 30 & 30 & - & - & 2 & Po & - \\
\hline & 31 & 9 & $50 \mathrm{KCl}-50 \mathrm{NaCl}$ & 1.4 & 0.2 & 0.0159 & 30 & 30 & - & - & 2 & Po & - \\
\hline & 32 & 11 & $32.8 \mathrm{NaCl}^{-67.2 \mathrm{CaCl}_{2}}$ & 4.5 & 2.1 & 0.1637 & 30 & 30 & 0.36 & 0.41 & 2 & Po & - \\
\hline \multirow[t]{6}{*}{6} & 33 & 4 & $44 \mathrm{Li}_{2} \mathrm{CO}_{3}-56 \mathrm{~K}_{2} \mathrm{CO}_{3}$ & 9.1 & 1.2 & 0.0923 & $<0.5$ & $<0.5$ & - & - & 2 & $\mathbf{P}_{0}$ & - \\
\hline & 34 & 11 & $32.8 \mathrm{NaCl}-67.2 \mathrm{CaCl}_{2}$ & 5.0 & 1.0 & 0.0778 & $<0.5$ & $<0.5$ & 0.28 & 0.31 & 2 & Po & - \\
\hline & 35 & 13 & $21 \mathrm{NaCl}-31 \mathrm{BaCl}_{2}-48 \mathrm{CaCl}_{2}$ & 5.0 & 0.8 & 0.0639 & $<0.5$ & $<0.5$ & - & - & 2 & Po & - \\
\hline & 36 & 10 & $46.2 \mathrm{LiCl}-53.8 \mathrm{KCl}$ & 7.5 & 0.1 & 0.0097 & $<0.5$ & $<0.5$ & 0.03 & 0.02 & 2 & Po & - \\
\hline & 37 & 15 & $30 \mathrm{LICl}-70 \mathrm{KCl}$ & 3.4 & 0.1 & 0.0085 & $<0.5$ & $<0.5$ & - & - & 2 & Po & - \\
\hline & 38 & 14 & $25 \mathrm{NaCl}-25 \mathrm{LiCl}-50 \mathrm{KCl}$ & 3.8 & 0.1 & 0.0077 & $<0.5$ & $<0.5$ & - & - & 2 & Po & - \\
\hline \multirow[t]{6}{*}{7} & 39 & 6 & $24 \mathrm{NaCl}-28 \mathrm{KCl}-48 \mathrm{BaCl}_{2}$ & - & 1.2 & 0.0952 & 20 & 20 & - & - & 2 & Po & - \\
\hline & 40 & 4 & $44 \mathrm{Li}_{2} \mathrm{CO}_{3}-56 \mathrm{~K}_{2} \mathrm{CO}_{3}$ & 5.6 & 3.0 & 0.2391 & 20 & 20 & - & - & 2 & Ms & - \\
\hline & 41 & 15 & $30 \mathrm{LICl}-70 \mathrm{KCl}$ & 5.1 & 0.06 & 0.0045 & 20 & 20 & - & - & 2 & Po & - \\
\hline & 42 & 14 & $25 \mathrm{NaCl}-25 \mathrm{LiCl}-50 \mathrm{KCl}$ & 2.9 & 0.05 & 0.0044 & 20 & 20 & - & - & 2 & ro & - \\
\hline & 43 & 13 & $21 \mathrm{NaCl} \cdot 31 \mathrm{BaCl}_{2} \tau^{48 \mathrm{CaCl}} 2$ & - & 1.3 & 0.1026 & 20 & 20 & - & - & 2 & Po & - \\
\hline & 44 & 4 & $44 \mathrm{Li}_{2} \mathrm{CO}_{3}-56 \mathrm{~K}_{2} \mathrm{CO}_{3}$ & 4.1 & 1.7 & 0.1282 & 20 & 20 & 1.20 & - & 2 & Po & - \\
\hline
\end{tabular}

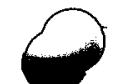


TABLE A-2. (Continued)

\begin{tabular}{|c|c|c|c|c|c|c|c|c|c|c|c|c|c|}
\hline \multirow[b]{2}{*}{ Run } & \multirow[b]{2}{*}{$\begin{array}{l}\text { Uranium } \\
\text { Specimen }\end{array}$} & \multirow[b]{2}{*}{$\begin{array}{l}\text { Salt } \\
\text { Mix }\end{array}$} & \multirow[b]{2}{*}{$\begin{array}{c}\text { Composition of } \\
\text { Salt Mix, } \\
w / 0\end{array}$} & \multirow[b]{2}{*}{$\begin{array}{c}\text { Hydrogen } \\
\text { Pickup, } \\
\text { ppm }\end{array}$} & \multirow[b]{2}{*}{$\begin{array}{l}\text { Weight } \\
\text { Loss, } \\
\text { per cent }\end{array}$} & \multirow[b]{2}{*}{$\begin{array}{c}\text { Weight } \\
\text { Loss, } \\
\text { g }\end{array}$} & \multicolumn{2}{|c|}{$\begin{array}{c}\text { Partial } \\
\text { Vapor Pressure } \\
\text { of Water, } \\
\text { mm mercury }\end{array}$} & \multicolumn{2}{|c|}{$\begin{array}{l}\text { Free Hydroxyl lon, } \\
\text { per cent } \\
\end{array}$} & \multirow[b]{2}{*}{$\begin{array}{l}\text { Aging } \\
\text { Period, } \\
\text { days }\end{array}$} & \multirow[b]{2}{*}{$\begin{array}{c}\text { Type } \\
\text { of } \\
\text { Crucible }(a)\end{array}$} & \multirow[b]{2}{*}{ Notes } \\
\hline & & & & & & & $\begin{array}{l}\text { At Time } \\
\text { Uranium } \\
\text { Treated } \\
\end{array}$ & $\begin{array}{c}\text { For } \\
\text { Aging } \\
\text { Period } \\
\end{array}$ & $\begin{array}{l}\text { Before } \\
\text { Uranium } \\
\text { Treated }\end{array}$ & $\begin{array}{c}\text { After } \\
\text { Uranium } \\
\text { Treated }\end{array}$ & & & \\
\hline \multirow[t]{5}{*}{9} & 56 & 22 & $50 \mathrm{Na}_{2} \mathrm{CO}_{3}-50 \mathrm{~K}_{2} \mathrm{CO}_{3}$ & 6.7 & - & 0.1486 & $<0.5$ & $<0.5$ & - & 1.96 & 7 & Po & - \\
\hline & 57 & 18 & $19 \mathrm{NaCl}-34 \mathrm{CaCl}_{2}-47 \mathrm{KCl}$ & 13.5 & - & 0.0385 & $<0.5$ & $<0.5$ & - & 0.07 & 7 & Po & - \\
\hline & 58 & 17 & $33 \mathrm{NaCl}-33 \mathrm{KCl}-33 \mathrm{Na}_{2} \mathrm{CO}_{3}$ & 3.3 & - & 0.3138 & $<0.5$ & $<0.5$ & - & - & 7 & Po & - \\
\hline & 59 & 5 & $50 \mathrm{KCl}-50 \mathrm{Na}_{2} \mathrm{CO}_{3}$ & 1.5 & - & 0.2794 & $<0.5$ & $<0.5$ & - & 0.38 & 7 & $P_{0}$ & - \\
\hline & 60 & 9 & $50 \mathrm{KCl}-50 \mathrm{NaCl}$ & 0.9 & - & 0.0513 & $<0.5$ & $<0.5$ & - & 0.06 & 7 & Po & - \\
\hline \multirow[t]{5}{*}{10} & 66 & 18 & $19 \mathrm{NaCl}-34 \mathrm{CaCl}_{2}-47 \mathrm{KCl}$ & - & 0.4 & 0.0279 & 80 & 80 & - & 0.09 & 7 & $P_{0}$ & - \\
\hline & 67 & - & - & - & - & - & 80 & 80 & - & - & 7 & $\mathrm{Po}_{0}$ & - \\
\hline & 68 & 9 & $50 \mathrm{KCl}-50 \mathrm{NaCl}$ & 2.8 & 0.02 & 0.0017 & 80 & 80 & - & 0.00 & 7 & Po & - \\
\hline & 69 & Blank & - & $<0.1$ & - & - & 80 & 80 & - & - & 7 & Po & $\sim$ \\
\hline & 70 & 4 & $44 \mathrm{Li}_{2} \mathrm{CO}_{3}-56 \mathrm{~K}_{2} \mathrm{CO}_{3}$ & 12.3 & 0.1 & 0.0072 & 80 & 80 & - & 1.73 & 7 & $\mathrm{P}_{0}$ & $\cdot-$ \\
\hline \multirow[t]{5}{*}{11} & 71 & 18 & $19 \mathrm{NaCl}-34 \mathrm{CaCl}_{2}-47 \mathrm{KCl}$ & 13.9 & 0.01 & 0.0005 & $<0.5$ & $<0.5$ & - & - & 7 & Po & - \\
\hline & 72 & 9 & $50 \mathrm{KCl}-50 \mathrm{NaCl}$ & 1.1 & 0.05 & 0.0043 & $<0.5$ & $<0.5$ & - & - & 7 & Po & - \\
\hline & 73 & 4 & $44 \mathrm{Li}_{2} \mathrm{CO}_{3}-56 \mathrm{~K}_{2} \mathrm{CO}_{3}$ & 11.9 & 1.5 & 0.1117 & $<0.5$ & $<0.5$ & - & - & 7 & Po & - \\
\hline & 74 & 14 & $25 \mathrm{NaCl}-25 \mathrm{LiCl}-50 \mathrm{KCl}$ & 9.8 & 4.3 & 0.3758 & $<0.5$ & $<0.5$ & - & - & 7 & Po & - \\
\hline & 75 & 4 & $44 \mathrm{Li}_{2} \mathrm{CO}_{3}-56 \mathrm{~K}_{2} \mathrm{CO}_{3}$ & 10.3 & 1.1 & 0.0882 & $<0.5$ & $<0.5$ & - & - & 7 & Po & - \\
\hline Room & 76 & 6 & $24 \mathrm{NaCl}-28 \mathrm{KCl}-48 \mathrm{BaCl}_{2}$ & 2.3 & 0.03 & 0.0018 & - & - & - & 0.017 & 7 & Vy & - \\
\hline atmosphere & 77 & 9 & $50 \mathrm{KCl}-50 \mathrm{NaCl}$ & 0.8 & 0.08 & 0.0054 & - & - & - & None & 7 & Vy & - \\
\hline \multirow[t]{2}{*}{$(4 / 20)$} & 78 & 14 & $25 \mathrm{NaCl}-25 \mathrm{LiCl}-50 \mathrm{KCl}$ & 5.6 & 0.06 & 0.0043 & - & - & - & 0.022 & 7 & Vy & - \\
\hline & 79 & 18 & $19 \mathrm{NaCl}-34 \mathrm{CaCl}_{2^{-47}} \mathrm{KCl}$ & 16.0 & 0.06 & 0.0043 & - & - & - & 0.035 & 7 & Vy & - \\
\hline \multirow[t]{8}{*}{12} & 80 & 4 & $44 \mathrm{Li}_{2} \mathrm{CO}_{3}-56 \mathrm{~K}_{2} \mathrm{CO}_{3}$ & 12.9 & 1.6 & 0.1077 & 70 & 70 & 2.13 & 1.92 & 5 & $\mathrm{Pt}$ & - \\
\hline & 81 & 4 & $44 \mathrm{Li}_{2} \mathrm{CO}_{3}-56 \mathrm{~K}_{2} \mathrm{CO}_{3}$ & 13.7 & 1.9 & 0.1344 & 70 & 70 & 2.13 & 1.86 & 5 & $P t$ & - \\
\hline & 82 & 20 & $25 \mathrm{Li}_{2} \mathrm{CO}_{3}-75 \mathrm{~K}_{2} \mathrm{CO}_{3}$ & 13.2 & 1.5 & 0.1063 & 70 & 70 & 0.72 & 0.72 & 5 & $\mathrm{Pt}$ & - \\
\hline & 83 & 20 & $25 \mathrm{Li}_{2} \mathrm{CO}_{3}-75 \mathrm{~K}_{2} \mathrm{CO}_{3}$ & 13.5 & 1.2 & 0.0883 & 70 & 70 & 0.72 & - & 5 & $\mathrm{Pt}$ & - \\
\hline & 84 & 4 & $44 \mathrm{Li}_{2} \mathrm{CO}_{3}-56 \mathrm{~K}_{2} \mathrm{CO}_{3}$ & 6.4 & 1.9 & 0.1340 & $<0.5$ & $<0.5$ & 0.14 & 0.19 & 5 & $\mathrm{Pt}$ & - \\
\hline & 85 & 4 & $44 \mathrm{Li}_{2} \mathrm{CO}_{3}-56 \mathrm{~K}_{2} \mathrm{CO}_{3}$ & 4.5 & - & - & $<0.5$ & $<0.5$ & 0.14 & 0.19 & 5 & $\mathrm{Pl}$ & - \\
\hline & 86 & 20 & $25 \mathrm{Li}_{2} \mathrm{CO}_{3}-75 \mathrm{~K}_{2} \mathrm{CO}_{3}$ & 5.0 & 1.7 & 0.1187 & $<0.5$ & $<0.5$ & 0.03 & 0.06 & 5 & $\mathrm{Pt}$ & - \\
\hline & 87 & 20 & $25 \mathrm{Li}_{2} \mathrm{CO}_{3} \cdot 75 \mathrm{~K}_{2} \mathrm{CO}_{3}$ & 4.9 & 2.2 & 0.1508 & $<0.5$ & $<0.5$ & 0.03 & 0.08 & 5 & $\mathrm{Pt}$ & - \\
\hline Room & 88 & 6 & $24 \mathrm{NaCl}-28 \mathrm{KCl}-48 \mathrm{BaCl}_{2}$ & 7.7 & 0.09 & 0.0065 & - & - & 0.39 & - & 7 & vy & - \\
\hline atmosphere & 89 & 9 & $50 \mathrm{KCl}-50 \mathrm{NaCl}$ & 2.5 & 0.12 & 0.0082 & - & - & 0.00 & - & 7 & Vy & - \\
\hline \multirow[t]{2}{*}{$(4 / 27)$} & 90 & 14 & $25 \mathrm{NaCl}-25 \mathrm{LiCl}-50 \mathrm{KCl}$ & 2.0 & 0.08 & 0.0057 & - & - & 0.31 & - & 7 & Vy & - \\
\hline & 91 & 18 & $19 \mathrm{NaCl}-34 \mathrm{CaCl}_{2}-47 \mathrm{KCl}$ & 12.3 & 0.10 & 0.0067 & - & - & 0.75 & - & 7 & Vy & - \\
\hline \multirow[t]{8}{*}{13} & 92 & 5 & $50 \mathrm{KCl}-50 \mathrm{Na}_{2} \mathrm{CO}_{3}$ & 4.7 & 3.1 & 0.2179 & 70 & 70 & 0.32 & 0.40 & 7 & $\mathrm{Pt}$ & - \\
\hline & 93 & 5 & $50 \mathrm{KCl}-50 \mathrm{Na}_{2} \mathrm{CO}_{3}$ & - & 3.9 & 0.2727 & 70 & 70 & 0.32 & 0.36 & 7 & Pt & - \\
\hline & 94 & 17 & $33 \mathrm{NaCl}-33 \mathrm{KCl}-33 \mathrm{Na}_{2} \mathrm{CO}_{3}$ & - & 3.2 & 0.2155 & 70 & 70 & 0.41 & 0.42 & 7 & $\mathrm{Pt}$ & - \\
\hline & 95 & 17 & $33 \mathrm{NaCl}-33 \mathrm{KCl}-33 \mathrm{Na}_{2} \mathrm{CO}_{3}$ & 2.7 & 4.2 & 0.2836 & 70 & 70 & 0.41 & 0.40 & 7 & $\mathrm{Pt}$ & - \\
\hline & 96 & 5 & $50 \mathrm{KCl}-50 \mathrm{Na}_{2} \mathrm{CO}_{3}$ & 1.3 & 2.6 & 0.1768 & $<0.5$ & $<0.5$ & 0.06 & 0.06 & 7 & $\mathrm{Pt}$ & - \\
\hline & 97 & 5 & $50 \mathrm{KCl}-50 \mathrm{Na}_{2} \mathrm{CO}_{3}$ & 1.9 & 2.7 & 0.1860 & $<0.5$ & $<0.5$ & 0.06 & 0.05 & 7 & $\mathrm{Pt}$ & - \\
\hline & 98 & 17 & $33 \mathrm{NaCl}-33 \mathrm{KCl}-33 \mathrm{Na}_{2} \mathrm{CO}_{3}$ & 2.4 & 2.7 & 0.1876 & $<0.5$ & $<0.5$ & 0.08 & 0.05 & 7 & $\mathrm{Pt}$ & - \\
\hline & 99 & 17 & $33 \mathrm{NaCl}-33 \mathrm{KCl}-33 \mathrm{Na}_{2} \mathrm{CO}_{3}$ & 1.3 & 3.5 & 0.2448 & $<0.5$ & $<0.5$ & 0.08 & 0.06 & 7 & $\mathrm{Pt}$ & - \\
\hline Room & 100 & 6 & $24 \mathrm{NaCl}-28 \mathrm{KCl}-48 \mathrm{BaCl}_{2}$ & 9.8 & 0.11 & 0.0077 & 8.5 & - & 0.04 & - & 7 & Vy & - \\
\hline atmosphere & 101 & 9 & $50 \mathrm{KCl}-50 \mathrm{NaCl}$ & 12.5 & 0.10 & 0.0073 & 8.5 & - & 0.01 & - & 7 & Vy & - \\
\hline \multirow[t]{2}{*}{$(5 / 4)$} & 102 & 14 & $25 \mathrm{NaCl}-25 \mathrm{LiCl}-50 \mathrm{KCl}$ & 12.1 & 0.13 & 0.0088 & 8.5 & - & 0.05 & - & 7 & Vy & - \\
\hline & 103 & 18 & $19 \mathrm{NaCl}-34 \mathrm{CaCl}_{2}^{-47} \mathrm{KCl}$ & 12.5 & 0.26 & 0.0182 & 8.5 & - & 0.15 & - & 7 & vy & - \\
\hline
\end{tabular}




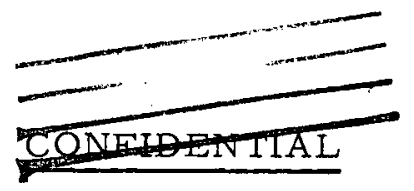

A -4

TABLE A-2. (Continued)

\begin{tabular}{|c|c|c|c|c|c|c|c|c|c|c|c|c|c|}
\hline \multirow[b]{2}{*}{ Run } & \multirow[b]{2}{*}{$\begin{array}{l}\text { Uranium } \\
\text { Specimen }\end{array}$} & \multirow[b]{2}{*}{$\begin{array}{l}\text { Salt } \\
\text { Mix }\end{array}$} & \multirow[b]{2}{*}{$\begin{array}{c}\text { Composition of } \\
\text { Salt Mix, } \\
w / 0\end{array}$} & \multirow[b]{2}{*}{$\begin{array}{l}\text { Hydrogen } \\
\text { Pickup, } \\
\text { ppm }\end{array}$} & \multirow[b]{2}{*}{$\begin{array}{l}\text { Weight } \\
\text { Loss, } \\
\text { per cent }\end{array}$} & \multirow[b]{2}{*}{$\begin{array}{l}\text { Weight } \\
\text { Loss, } \\
\text { g }\end{array}$} & \multicolumn{2}{|c|}{$\begin{array}{c}\text { Partial } \\
\text { Vapor Pressure } \\
\text { of Water, } \\
\text { mm mercury } \\
\end{array}$} & \multicolumn{2}{|c|}{$\begin{array}{l}\text { Free Hydroxyl Ion, } \\
\text { per cent } \\
\end{array}$} & \multirow[b]{2}{*}{$\begin{array}{l}\text { Aging } \\
\text { Period, } \\
\text { days }\end{array}$} & \multirow[b]{2}{*}{$\begin{array}{c}\text { Type } \\
\text { of } \\
\text { Crucible } \\
\text { (a) }\end{array}$} & \multirow[b]{2}{*}{ Notes } \\
\hline & & & & & & & $\begin{array}{l}\text { At Time } \\
\text { Uranium } \\
\text { Treated }\end{array}$ & $\begin{array}{l}\text { For } \\
\text { Aging } \\
\text { Period }\end{array}$ & $\begin{array}{c}\text { Before } \\
\text { Uranium } \\
\text { Treated }\end{array}$ & $\begin{array}{l}\text { After } \\
\text { Uranium } \\
\text { Treated }\end{array}$ & & & \\
\hline \multirow[t]{8}{*}{14} & 104 & 9 & $50 \mathrm{KCl}-50 \mathrm{NaCl}$ & 9.0 & 7.5 & 0.5010 & 70 & 70 & 0.0 & 0.0 & 7 & Pt & - \\
\hline & 105 & 9 & $50 \mathrm{KCl}-50 \mathrm{NaCl}$ & 6.4 & 6.9 & 0.4776 & 70 & 70 & 0.0 & 0.0 & 7 & $\mathrm{Pt}$ & - \\
\hline & 106 & 14 & $25 \mathrm{NaCl}-25 \mathrm{LiCl}-50 \mathrm{KCl}$ & 4.3 & 2.8 & 0.1977 & 70 & 70 & - & 0.01 & 7 & Pt & - \\
\hline & 107 & 14 & $25 \mathrm{NaCl}-25 \mathrm{LiCl}-50 \mathrm{KCl}$ & 7.3 & 4.2 & 0.2862 & 70 & 70 & - & 0.09 & 7 & $\mathrm{Pt}$ & - \\
\hline & 108 & 9 & $50 \mathrm{KCl}-50 \mathrm{NaCl}$ & 5.5 & 25.2 & 1.4552 & $<0.5$ & $<0.5$ & 0.0 & 0.02 & 7 & Pt & - \\
\hline & 109 & 9 & $50 \mathrm{KCl}-50 \mathrm{NaCl}$ & 5.4 & 33.4 & 2.3331 & $<0.5$ & $<0.5$ & 0.0 & 0.13 & 7 & $\mathrm{Pt}$ & - \\
\hline & 110 & 14 & $25 \mathrm{NaCl}-25 \mathrm{LiCl}-50 \mathrm{KCl}$ & 7.2 & 6.5 & 0.4500 & $<0.5$ & $<0.5$ & 0.01 & 0.0 & 7 & Pt & - \\
\hline & 111 & 14 & $25 \mathrm{NaCl}-25 \mathrm{LiCl}-50 \mathrm{KCl}$ & 7.9 & 8.6 & 0.6120 & $<0.5$ & $<05$ & 0.01 & 0.0 & 7 & $\mathrm{Pt}$ & - \\
\hline Room & 112 & 6 & $24 \mathrm{NaCl}-28 \mathrm{KCl}-48 \mathrm{BaCl}_{2}$ & 11.1 & 0.003 & 0.0002 & 18 & 11 & 0.05 & - & 7 & vy & - \\
\hline atmosphere & 113 & 9 & $50 \mathrm{KCl}-50 \mathrm{NaCl}$ & 3.5 & 0.01 & 0.0010 & 18 & 11 & 0.01 & - & 7 & vy & - \\
\hline \multirow[t]{2}{*}{$(5 / 11)$} & 114 & 14 & $25 \mathrm{NaCl}-25 \mathrm{LICl}-50 \mathrm{KCl}$ & 12.3 & 0.12 & 0.0085 & 18 & 11 & 0.06 & - & 7 & vy & - \\
\hline & 115 & 18 & $19 \mathrm{NaCl}^{34} \mathrm{CaCl}_{2}-47 \mathrm{KCl}$ & 12.8 & 0.26 & 0.0175 & 18 & 11 & 0.15 & - & 7 & vy & - \\
\hline \multirow[t]{8}{*}{15} & 116 & 21 & $15 \mathrm{Li}_{2} \mathrm{CO}_{3}-37 \mathrm{~K}_{2} \mathrm{CO}_{3}-48 \mathrm{Na}_{2} \mathrm{CO}_{3}$ & 14.2 & 1.7 & 0.1128 & 70 & 70 & 0.65 & 0.68 & 6 & $\mathrm{Pt}$ & - \\
\hline & 117 & 21 & $15 \mathrm{Li}_{2} \mathrm{CO}_{3}-37 \mathrm{~K}_{2} \mathrm{CO}_{3}-48 \mathrm{Na}_{2} \mathrm{CO}_{3}$ & 9.8 & 2.3 & 0.1556 & 70 & 70 & 0.65 & 0.57 & 6 & Pt & - \\
\hline & 118 & 5 & $50 \mathrm{KCl}-50 \mathrm{Na}_{2} \mathrm{CO}_{3}$ & 4.0 & 4.1 & 0.2837 & 70 & 70 & 0.38 & 0.58 & 6 & $\mathrm{Pt}$ & - \\
\hline & 119 & 5 & $50 \mathrm{KCl}-50 \mathrm{Na}_{2} \mathrm{CO}_{3}$ & - & 2.7 & 0.1768 & 70 & 70 & 0.38 & 0.61 & 6 & $\mathrm{Pt}$ & - \\
\hline & 120. & 21 & $15 \mathrm{Li}_{2} \mathrm{CO}_{3}-37 \mathrm{~K}_{2} \mathrm{CO}_{3}-48 \mathrm{Na}_{2} \mathrm{CO}_{3}$ & - & 5.6 & 0.3921 & $<0.5$ & $<0.5$ & 0.13 & 0.10 & 6 & $\mathrm{Pt}$ & - \\
\hline & $121^{\circ}$ & 21 & $15 \mathrm{Li}_{2} \mathrm{CO}_{3}-37 \cdot \mathrm{K}_{2} \mathrm{CO}_{3}-48 \mathrm{Na}_{2} \mathrm{CO}_{3}$ & 6.6 & 0.7 & 0.0466 & $<0.5$ & $<0.5$ & 0.13 & 0.17 & 6 & $\mathrm{Pt}$ & - \\
\hline & 122 & 5 & $50 \mathrm{KCl}-50 \quad \mathrm{Na}_{2} \mathrm{CO}_{3}$ & 2.7 & 4.0 & 0.2797 & $<0.5$ & $<0.5$ & 0.07 & 0.06 & 6 & $\mathrm{Pt}$ & - \\
\hline & 123 & 5 & $50 \mathrm{KCl}-50 \mathrm{Na}_{2} \mathrm{CO}_{3}$ & 4.2 & 2.2 & 0.1580 & $<0.5$ & $<0.5$ & 0.07 & 0.05 & 6 & $\mathrm{Pt}$ & - \\
\hline Room & 124 & 6 & $24 \mathrm{NaCl}-28 \mathrm{KCl}-48 \mathrm{BaCl}_{2}$ & 7.7 & 0.09 & 0.0062 & 7.9 & 12 & 0.08 & - & 7 & vy & - \\
\hline atmosphere & 125 & 9 & $50 \mathrm{KCl}-50 \mathrm{NaCl}$ & 2.0 & 0.06 & 0.0039 & 7.9 & 12 & 0.005 & - & 7 & vy & - \\
\hline \multirow[t]{2}{*}{$(5 / 18)$} & 126 & 14 & $25 \mathrm{NaCl}-25 \mathrm{LiCl}-50 \mathrm{KCl}$ & 11.6 & 0.19 & 0.0126 & 7.9 & 12 & 0.04 & - & 7 & vy & - \\
\hline & 127 & 18 & $19 \mathrm{NaCl}-34 \mathrm{CaCl}_{2}-47 \mathrm{KCl}$ & 11.8 & 0.45 & 0.0307 & 7.9 & 12 & 0.21 & - & 7 & Vy & - \\
\hline \multirow[t]{8}{*}{16} & 128 & 17 & $33 \mathrm{NaCl}-33 \mathrm{KCl}-33 \mathrm{Na}_{2} \mathrm{CO}_{3}$ & 5.3 & 3.4 & .0 .2363 & 70 & 70 & 0.65 & 0.75 & 6 & $\mathrm{Pt}$ & - \\
\hline & 129 & 17 & $33 \mathrm{NaCl}-33 \mathrm{KCl}-33 \mathrm{Na}_{2} \mathrm{CO}_{3}$ & 4.1 & 3.3 & 0.2294 & 70 & 70 & 0.65 & 0.75 & 6 & $\mathrm{Pt}$ & - \\
\hline & 130 & 17 & $33 \mathrm{NaCl}-33 \mathrm{KCl}-33 \mathrm{Na}_{2} \mathrm{CO}_{3}$ & 2.4 & 3.6 & 0.2574 & $<0.5$ & $<0.5$ & 0.10 & 0.05 & 6 & $\mathrm{Pt}$ & - \\
\hline & 131 & 17 & $33 \mathrm{NaCl}-33 \mathrm{KCl}-33 \mathrm{Na}_{2} \mathrm{CO}_{3}$ & 1.5 & 3.8 & 0.2608 & $<0.5$ & $<0.5$ & 0.10 & 0.07 & 6 & $\mathrm{Pt}$ & - \\
\hline & 132 & 4 & $44 \mathrm{Li}_{2} \mathrm{CO}_{2}-56 \mathrm{~K}_{2} \mathrm{CO}_{3}$ & 5.2 & 2.0 & 0.1360 & $<0.5$ & $<0.5$ & - & 0.20 & 6 & $\mathrm{Pt}$ & - \\
\hline & 133 & 4 & $44 \mathrm{Li}_{2} \mathrm{CO}_{3}-56 \mathrm{~K}_{2} \mathrm{CO}_{3}$ & 8.8 & 1.7 & 0.1196 & $<0.5$ & $<0.5$ & - & 0.19 & 6 & Pt & - \\
\hline & 134 & $4+\mathrm{KOH}$ & $\begin{array}{l}93.4\left(44 \mathrm{Li}_{2} \mathrm{CO}_{3}+56 \mathrm{~K}_{2} \mathrm{CO}_{3}\right) \\
-6.6 \mathrm{KOH}\end{array}$ & 7.0 & 2.3 & 0.1570 & $<0.5$ & $<0.5$ & - & 0.18 & 6 & $\mathrm{Pt}$ & - \\
\hline & 135 & $4+\mathrm{KOH}$ & $\begin{array}{l}93.4\left(44 \mathrm{Li}_{2} \mathrm{CO}_{3}+56 \mathrm{~K}_{2} \mathrm{CO}_{3}\right) \\
-6.6 \mathrm{KOH}\end{array}$ & 7.4 & 2.0 & 0.1383 & $<0.5$ & $<0.5$ & - & 0.15 & 6 & $\mathrm{Pt}$ & - \\
\hline Room & 136 & 6 & $24 \mathrm{NaCl}-28 \mathrm{KCl}-48 \mathrm{BaCl}_{2}$ & 4.3 & 0.08 & 0.0051 & 5.5 & 10 & 0.13 & - & 7 & $v_{y}$ & - \\
\hline atmosphere & 137 & 9 & $50 \mathrm{KCl}-50 \mathrm{NaCl}$ & 1.2 & 0.08 & 0.0048 & 5.5 & 10 & 0.01 & - & 7 & vy & - \\
\hline \multirow[t]{2}{*}{$(5 / 25)$} & 138 & 14 & $25 \mathrm{NaCl}-25 \mathrm{LiCl}-50 \mathrm{KCl}$ & 9.9 & 0.08 & 0.0050 & 5.5 & 10 & 0.09 & - & 7 & vy & - \\
\hline & 139 & 18 & $19 \mathrm{NaCl}-34 \mathrm{CaCl}_{2}-47 \mathrm{KCl}$ & 9.9 & 0.27 & 0.0157 & 5.5 & 10 & 0.22 & - & 7 & vy & - \\
\hline 17 & 140 & 9 & $50 \mathrm{KCl}-50 \mathrm{NaCl}$ & 8.1 & 0.6 & 0.0415 & 70 & 70 & 0.01 & 0.005 & 6 & Pt-Vy & - \\
\hline & 141 & 9 & $50 \mathrm{KCl}-50 \mathrm{NaCl}$ & 9.9 & 0.3 & 0.0017 & 70 & 70 & 0.01 & 0.0 & 6 & Po-Vy & - \\
\hline & 142 & 9 & $50 \mathrm{KCl}-50 \mathrm{NaCl}$ & 2.2 & 2.1 & 0.1453 & 70 & 70 & 0.01 & 0.0 & 6 & Pt-Vy & - \\
\hline & 143 & 14 & $25 \mathrm{NaCl}-34 \mathrm{CaCl}_{2}-47 \mathrm{KCl}$ & 2.9 & 2.7 & 0.1766 & 70 & 70 & 0.16 & 0.13 & 6 & Pt-Vy & - \\
\hline & 144 & 14 & $25 \mathrm{NaCl}-34 \mathrm{CaCl}_{2}-47 \mathrm{KCl}$ & 4.5 & 2.7 & 0.1796 & 70 & 70 & 0.16 & 0.12 & 6 & $P t-V y$ & - \\
\hline & 145 & 9 & $50 \mathrm{KCl}-50 \mathrm{NaCl}$ & 11.9 & 0.3 & 0.0178 & $<0.5$ & $<0.5$ & 0.0 & 0.0 & 6 & $P t-V y$ & - \\
\hline & 146 & 9 & $50 \mathrm{KCl}-50 \mathrm{NaCl}$ & 10.9 & 0.07 & 0.0052 & $<0.5$ & $<0.5$ & 0.0 & 0.0 & 6 & Po-Vy & - \\
\hline & 147 & 9 & $50 \mathrm{KCl} \cdot 50 \mathrm{NaCl}$ & 0.5 & 0.02 & 0.0019 & $<0.5$ & $<0.5$ & 0.0 & 0.0 & 6 & PtVy & - \\
\hline & 148 & 14 & $25 \mathrm{NaCl}-34 \mathrm{CaCl}_{2}-47 \mathrm{kCl}$ & 7.4 & 0.2 & 0.0151 & $<0.5$ & $<0.5$ & 0.13 & 0.02 & 6 & Pt-Vy & - \\
\hline & 149 & 14 & $25 \mathrm{NaCl}-34 \mathrm{CaCl}_{2}-47 \mathrm{KCl}$ & 9.3 & 0.2 & 0.0134 & $<0.5$ & $<0.5$ & 0.13 & 0.02 & 6 & $P t-V y$ & - \\
\hline
\end{tabular}




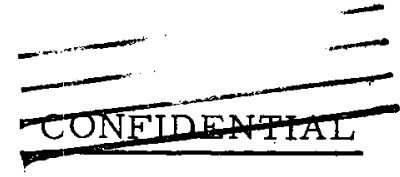

A-5 and A-6

TABLE A.2. (Continued)

\begin{tabular}{|c|c|c|c|c|c|c|c|c|c|c|c|c|c|}
\hline \multirow[b]{2}{*}{ Run } & \multirow[b]{2}{*}{$\begin{array}{l}\text { Uranium } \\
\text { Specimen }\end{array}$} & \multirow[b]{2}{*}{$\begin{array}{l}\text { Salt } \\
\text { Mix }\end{array}$} & \multirow[b]{2}{*}{$\begin{array}{c}\text { Composition of } \\
\text { Salt Mix, } \\
w / 0\end{array}$} & \multirow{2}{*}{$\begin{array}{c}\text { Hydrogen, } \\
\text { Pickup, } \\
\text { ppm }\end{array}$} & \multirow[b]{2}{*}{$\begin{array}{l}\text { Weight } \\
\text { Loss, } \\
\text { per cent }\end{array}$} & \multirow[b]{2}{*}{$\begin{array}{l}\text { Weight } \\
\text { Loss, } \\
\mathrm{g}\end{array}$} & \multicolumn{2}{|c|}{$\begin{array}{c}\text { Partial } \\
\text { Vapor Pressure } \\
\text { of Water, } \\
\text { mim mercury } \\
\end{array}$} & \multicolumn{2}{|c|}{$\begin{array}{l}\text { Free Hydroxyl lon, } \\
\text { per cent }\end{array}$} & \multirow[b]{2}{*}{$\begin{array}{l}\text { Aging } \\
\text { Period, } \\
\text { days }\end{array}$} & \multirow[b]{2}{*}{$\begin{array}{c}\text { Type } \\
\text { of } \\
\text { Crucible }\end{array}$} & \multirow[b]{2}{*}{ Notes } \\
\hline & & & & & & & $\begin{array}{l}\text { At Time } \\
\text { Uranium } \\
\text { Treated } \\
\end{array}$ & $\begin{array}{c}\text { For } \\
\text { Aging } \\
\text { Period }\end{array}$ & $\begin{array}{l}\text { Before } \\
\text { Uranium } \\
\text { Treated } \\
\end{array}$ & $\begin{array}{l}\text { After } \\
\text { Uranium } \\
\text { Treated } \\
\end{array}$ & & & \\
\hline Room & 150 & 6 & $24 \mathrm{NaCl}-28 \mathrm{KCl}-48 \mathrm{BaCl}_{2}$ & 6.1 & 0.002 & 0.0001 & 9.5 & 13 & 0.18 & - & 7 & vy & - \\
\hline Atmosphere & 151 & 9 & $50 \mathrm{KCl}-50 \mathrm{NaCl}$ & 2.7 & 0.0 & 0.0000 & 9.5 & 13 & 0.01 & - & 7 & vy & - \\
\hline \multirow[t]{2}{*}{$(6 / 1)$} & 152 & 14 & $25 \mathrm{NaCl}-25 \mathrm{LiCl}-50 \mathrm{KCl}$ & - & - & - & 9.5 & 13 & - & - & 7 & Vy & Tube cracked, salt goni? \\
\hline & 153 & 18 & $19 \mathrm{NaCl}-34 \mathrm{CaCl}_{2}-47 \mathrm{KCl}$ & 8.3 & 0.07 & 0.0049 & 9.5 & 13 & 0.21 & - & 7 & Vy & - \\
\hline \multirow[t]{8}{*}{18} & 154 & 4 & $44 \mathrm{Li}_{2} \mathrm{CO}_{3}-56 \mathrm{~K}_{2} \mathrm{CO}_{3}$ & 6.9 & 1.1 & 0.0744 & $<0.5$ & $<0.5$ & 0.11 & 0.11 & 3 & $P t-V y$ & Atmosphere was $\mathrm{CO}_{2}$-free \\
\hline & 155 & 4 & $44 \mathrm{Li}_{2} \mathrm{CO}_{3}-56 \mathrm{~K}_{2} \mathrm{CO}_{3}$ & 7.0 & 1.5 & 0.0938 & $<0.5$ & $<0.5$ & 0.11 & 0.09 & 3 & Ptivy & - \\
\hline & 156 & $4+\mathrm{KOH}$ & $\begin{array}{l}93.4\left(44 \mathrm{LiCO}_{3}+56 \mathrm{~K}_{2} \mathrm{CO}_{3}\right) \\
-6.6 \mathrm{KOH}\end{array}$ & 6.9 & 2.1 & 0.1347 & $<0.5$ & $<0.5$ & 0.19 & 0.23 & 3 & Pt.Vy & - \\
\hline & 157 & $4+\mathrm{KOH}$ & $\begin{array}{l}93.4\left(44 \mathrm{LiCO}_{3}+56 \mathrm{~K}_{2} \mathrm{CO}_{3}\right) \\
-6.6 \mathrm{KOH}\end{array}$ & 9.9 & 2.3 & 0.1426 & $<0.5$ & $<0.5$ & 0.19 & 0.18 & 3 & $P t-V y$ & - \\
\hline & 158 & 9 & $50 \mathrm{KCl}-50 \mathrm{NaCl}$ & 0.6 & 0.1 & 0.0069 & $<0.5$ & $<0.5$ & 0.01 & 0.05 & 3 & $P t-V y$ & - \\
\hline & 159 & 9 & $50 \mathrm{KCl}-50 \mathrm{NaCl}$ & 0.4 & 0.08 & 0.0050 & $<0.5$ & $<0.5$ & 0.01 & 0.01 & 3 & $P t \cdot V_{y}$ & - \\
\hline & 160 & $9+\mathrm{KOH}$ & $93.4(50 \mathrm{KCl}-50 \mathrm{NaCl})-6.6 \mathrm{KOH}$ & 4.8 & 2.3 & 0.1510 & $<0.5$ & $<0.5$ & 0.70 & 0.68 & 3 & Pt-Vy & - \\
\hline & 161 & $9+\mathrm{KOH}$ & $93.4(50 \mathrm{KCl}-50 \mathrm{NaCl})-6.6 \mathrm{KOH}$ & 4.9 & 2.3 & 0.1494 & $<0.5$ & $<0.5$ & 0.70 & 0.78 & 3 & $P t-V y$ & - \\
\hline Room: & 162 & 6 & $24 \mathrm{NaCl}-28 \mathrm{KCl}-48 \mathrm{BaCl}_{2}$ & 1.5 & 0.16 & 0.0115 & 11 & 12 & 0.01 & - & 10 & vy & New tube, old salt used \\
\hline atmosphere & 163 & 9 & $50 \mathrm{KCl}-50 \mathrm{NaCl}$ & 1.8 & 0.06 & 0.0045 & 11 & 12 & 0.01 & - & 10 & vy & New tube, old salt used \\
\hline \multirow[t]{3}{*}{$(6 / 11)$} & 164 & 4 & $44 \mathrm{Li}_{2} \mathrm{CO}_{3}-56 \mathrm{~K}_{2} \mathrm{CO}_{3}$ & 9.1 & 2.9 & 0.1874 & 11 & 12 & 0.44 & - & 10 & 304 SS & Fresh salt \\
\hline & 165 & 5 & $50 \mathrm{KCl}-50 \mathrm{Na}_{2} \mathrm{CO}_{3}$ & 2.8 & 2.8 & 0.1772 & 11 & 12 & 0.15 & - & 10 & 304 SS & Fresh salt \\
\hline & 166 & 20 & $25 \mathrm{Li}_{2} \mathrm{CO}_{3}-75 \mathrm{~K}_{2} \mathrm{CO}_{3}$ & 11.2 & 1.6 & 0.1030 & 11 & 12 & 0.36 & - & 10 & $304 \mathrm{SS}$ & Fresh salt \\
\hline \multirow[t]{8}{*}{19} & 167 & $\mathrm{~g}+\mathrm{KOH}$ & $93.4(50 \mathrm{KCl}-50 \mathrm{NaCl})-6.6 \mathrm{KOH}$ & 3.5 & 3.3 & 0.2211 & 70 & 70 & - & 0.71 & 6 & Pt-Vy & $\mathrm{CO}_{2} \tau^{\text {free }}$ \\
\hline & 168 & $9+\mathrm{KOH}$ & $93.4(50 \mathrm{KCl}-50 \mathrm{NaCl})-6.6 \mathrm{KOH}$ & 4.5 & 3.7 & 0.2447 & 70 & 70 & - & 0.48 & 6 & Pt-Vy & $\mathrm{CO}_{2}$ free \\
\hline & 169 & 9 & $50 \mathrm{KCl}-50 \mathrm{NaCl}$ & 10.1 & 0.1 & 0.0085 & 70 & 70 & 0.04 & 0.01 & 6 & $\mathrm{Pt}-\mathrm{Vy}$ & $\mathrm{CO}_{2}$-free \\
\hline & 170 & 9 & $50 \mathrm{KCl}-50 \mathrm{NaCl}$ & 8.2 & 0.4 & 0.0263 & 70 & 70 & 0.04 & Trace & 6 & $\mathrm{Pt}-\mathrm{Vy}$ & $\mathrm{CO} \gamma_{\text {free }}$ \\
\hline & 171 & $9+\mathrm{KOH}$ & $93.4(50 \mathrm{KCl}-50 \mathrm{NaCl})-6.6 \mathrm{KOH}$ & 3.5 & 3.2 & 0.2136 & $<0.5$ & $<0.5$ & 0.04 & 0.15 & 6 & Pt-Vy & Not $\mathrm{CO}_{2}$-free \\
\hline & 172 & $9+\mathrm{KOH}$ & $93.4(50 \mathrm{KCl}-50 \mathrm{NaCl})-6.6 \mathrm{KOH}$ & 2.7 & 2.6 & 0.1772 & $<0.5$ & $<0.5$ & 0.04 & 0.08 & 6 & Pt-Vy & Not $\mathrm{CO}_{2}$-free \\
\hline & 173 & 9 & $50 \mathrm{KCl}-50 \mathrm{NaCl}$ & 0.7 & 2.3 & 0.1522 & $<0.5$ & $<0.5$ & Trace & 0.0 & 6 & Pt-Vy & Not $\mathrm{CO}_{2}$-tree \\
\hline & 174 & 9 & $50 \mathrm{KCl}-50 \mathrm{NaCl}$ & 1.1 & 0.2 & 0.0121 & $<0.5$ & $<0.5$ & Trace & Trace & 6 & $P t-V_{y}$ & Not $\mathrm{CO}_{2}$-free \\
\hline Room & 175 & 6 & $24 \mathrm{NaCl}-28 \mathrm{KCl}-48 \mathrm{BaCl}_{2}$ & 2.6 & 0.10 & 0.0071 & 20 & 16 & 0.11 & - & 7 & Vy & - \\
\hline atmosphere & 176 & 9 & $50 \mathrm{KCl}-50 \mathrm{NaCl}$ & 3.6 & 0.05 & 0.0035 & 20 & 16 & 0.01 & - & 7 & Vy & - \\
\hline \multirow[t]{3}{*}{$(6 / 18)$} & 177 & 4 & $44 \mathrm{Li}_{2} \mathrm{CO}_{3}-56 \mathrm{~K}_{2} \mathrm{CO}_{3}$ & 7.3 & 2.6 & 0.1709 & 20 & 16 & Insoluble & - & 7 & Ms & Uranium pitted \\
\hline & 178 & 5 & $50 \mathrm{KCl}-50 \mathrm{Na}_{2} \mathrm{CO}_{3}$ & 3.1 & 4.1 & 0.2795 & 20 & 16 & 0.15 & - & 7 & Ms & - \\
\hline & 179 & 20 & $25 \mathrm{Li}_{2} \mathrm{CO}_{3}-75 \mathrm{~K}_{2} \mathrm{CO}_{3}$ & 8.1 & $1.6^{\circ}$ & 0.1044 & 20 & 16 & Insoluble & - & 7 & Ms & Uranium pitted \\
\hline \multirow[t]{4}{*}{$20 \mathrm{~A}$} & 180 & $9+\mathrm{KOH}$ & $93.4(50 \mathrm{KCl}-50 \mathrm{NaCl})-6.6 \mathrm{KOH}$ & 4.4 & 2.4 & 0.1630 & $<0.5$ & $<0.5$ & 0.12 & 0.05 & 1 & $P t-V y$ & $\mathrm{CO}_{2}$ free \\
\hline & 181 & $9+\mathrm{KOH}$ & $93.4(50 \mathrm{KCL}-50 \mathrm{NaCl}-6.6 \mathrm{KOH}$ & 4.6 & 2.0 & 0.1391 & $<0.5$ & $<0.5$ & 0.12 & 0.03 & 1 & $P t-V y$ & $\mathrm{CO}_{2}$ free \\
\hline & 182 & 9 & $50 \mathrm{KCl}-50 \mathrm{NaCl}$ & 1.6 & 0.2 & 0.0126 & $<0.5$ & $<0.5$ & 0.0 & 0.0 & 1 & Pt-Vy & $\mathrm{CO}_{2}$ free \\
\hline & 183 & 9 & $50 \mathrm{KCl}-50 \mathrm{NaCl}$ & 0.9 & 0.2 & 0.0162 & $<0.5$ & $<0.5$ & 0.0 & 0.0 & 1 & Pt-Vy & $\mathrm{CO}_{2}$ free \\
\hline $20 \mathrm{~B}$ & 184 & $9+\mathrm{KOH}$ & $93.4(50 \mathrm{KCl}-50 \mathrm{NaCl})-6.6 \mathrm{KOH}$ & 3.7 & 2.6 & 0.1719 & 70 & 70 & 0.01 & 0.14 & 5 & Pt-Vy & Not $\mathrm{CO}_{2}$-free \\
\hline$\cdot$ & 185 & 9 & $50 \mathrm{KCl}-50 \mathrm{NaCl}$ & 5.8 & 0.1 & 0.0082 & 70 & 70 & 0.01 & 0.0 & 5 & Pt-Vy & Not $\mathrm{CO}_{2}$-free \\
\hline $21 \mathrm{~A}$ & 186 & $9+\mathrm{KOH}$ & $93.4(50 \mathrm{KCl}-50 \mathrm{NaCl})-6.6 \mathrm{KOH}$ & 3.3 & 1.3 & 0.0872 & $<0.5$ & $<0.5$ & 0.01 & 0.06 & 2 & $P t-V y$ & $\mathrm{CO}_{2}$ free \\
\hline & 187 & 9 & $50 \mathrm{KCl}-50 \mathrm{NaCl}$ & 2.8 & 1.2 & 0.0809 & $<0.5$ & $<0.5$ & 0.0 & 0.05 & 2 & Pt-Vy & $\mathrm{CO}_{2}$ free \\
\hline Room & 188 & 6 & $24 \mathrm{NaCl}-28 \mathrm{KCl}-48 \mathrm{BaCl}_{2}$ & 3.9 & 0.11 & 0.0068 & 15 & 18 & 0.21 & - & 7 & Vy & - \\
\hline atmosphere & 189 & 9 & $50 \mathrm{KCl}-50 \mathrm{NaCl}$ & 2.9 & 0.30 & 0.0202 & 15 & 18 & 0.02 & - & 7 & Vy & - \\
\hline$(6 / 25)$ & 190 & 4 & $44 \mathrm{Li}_{2} \mathrm{CO}_{3}-56 \mathrm{~K}_{2} \mathrm{CO}_{3}$ & 14.1 & 2.3 & 0.1544 & 15 & 18 & Insoluble & - & 7 & Ms & - \\
\hline & 191 & 5 & $50 \mathrm{KCl}-50 \mathrm{Na}_{2} \mathrm{CO}_{3}$ & 3.1 & 4.4 & 0.3038 & 15 & 18 & 0.21 & - & 7 & Ms & - \\
\hline & 192 & 20 & $25 \mathrm{Li}_{2} \mathrm{CO}_{3}-75 \mathrm{~K}_{2} \mathrm{CO}_{3}$ & 5.8 & 1.9 & 0.1220 & 15 & 18 & Insoluble & - & 7 & Ms & - \\
\hline 21B & 193 & $9+\mathrm{KOH}$ & $93.4(50 \mathrm{KCl}-50 \mathrm{NaCl})-6.6 \mathrm{KOH}$ & 10.1 & 4.3 & 0.2920 & $<0.5$ & $<0.5$ & - & 0.50 & 1 & $P t-V y$ & Too little fused salt \\
\hline & 194 & $9+\mathrm{KOH}$ & $93.4(50 \mathrm{KCl}-50 \mathrm{NaCl})-6.6 \mathrm{KOH}$ & 4.1 & 1.9 & 0.1196 & $<0.5$ & $<0.5$ & - & 0.05 & 1 & Pt-Vy & - \\
\hline & 195 & 9 & $50 \mathrm{KCl}-50 \mathrm{NaCl}$ & 0.7 & 0.5 & 0.0324 & $<0.5$ & $<0.5$ & 0.01 & 0.01 & 1 & $\mathrm{Pt}-\mathrm{Vv}$ & - \\
\hline & 196 & 9 & $50 \mathrm{KCl}-50 \mathrm{NaCl}$ & 0.3 & 0.2 & 0.0109 & $<0.5$ & $<0.5$ & 0.01 & 0.0 & 1 & Pt-Vy & - \\
\hline
\end{tabular}

(a) $\mathrm{Po}=$ porcelain; $M s=$ mild steel; $\mathrm{Ag}=$ silver; $\mathrm{Vy}=$ Vycor; $\mathrm{Pt}=$ platinum; $304 \mathrm{SS}=$ Type 304 stainless steel. 


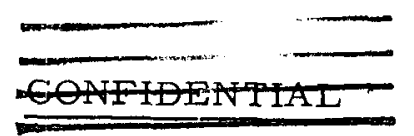

APPENDIX B

DATA FOR PART II

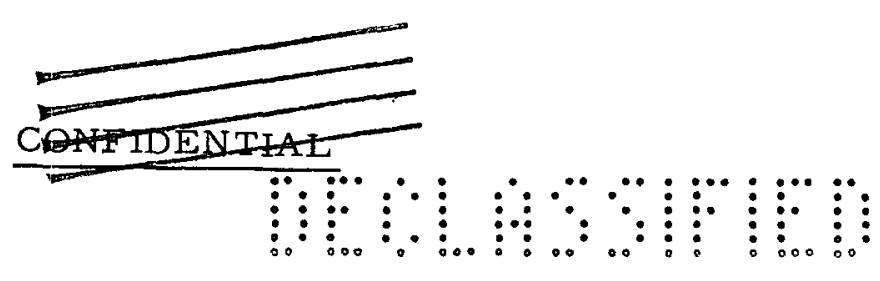


TABLE B-1. RESULTS AND CONDITIONS OF PILOT-PLANT RUNS

\begin{tabular}{|c|c|c|c|c|c|c|c|c|c|c|}
\hline \multirow[b]{2}{*}{ Specimen } & \multicolumn{2}{|c|}{$\begin{array}{c}\text { Salt Bath Composition, } \\
w / 0\end{array}$} & \multirow{2}{*}{$\begin{array}{c}\text { Final } \\
\text { Hydrogen } \\
\text { Content, } \\
\text { ppm } \\
\end{array}$} & \multicolumn{2}{|c|}{ Weight Loss } & \multirow{2}{*}{$\begin{array}{c}\text { Water-Vapor } \\
\text { Partial Pressure } \\
\text { at Time of Test, } \\
\text { mm mercury }\end{array}$} & \multirow{2}{*}{\multicolumn{2}{|c|}{$\begin{array}{c}\text { Water-Vapor } \\
\text { Partial Pressure } \\
\text { During Week } \\
\text { Prior to Test, } \\
\text { mm mercury } \\
\end{array}$}} & \multicolumn{2}{|c|}{$\begin{array}{c}\text { Hydraxyl-Ion } \\
\text { Content of } \\
\text { Salt Bath, w/o }\end{array}$} \\
\hline & Base & Contaminant & & Per Cent & $\mathrm{g}$ & & & & Before & After \\
\hline $1 \cdot 1-a$ & $93.5 \mathrm{~A}^{(\mathrm{a})}$ & $6.5 \mathrm{~B}^{(\mathrm{b})}$ & 0.51 & 0.20 & 1.8 & - & - & & 0.04 & - \\
\hline $1 \cdot 1-b$ & $93.5 \mathrm{~A}$ & $6.5 \mathrm{~B}$ & 0.21 & 0.13 & 1.3 & - & - & & 0.04 & - \\
\hline $1-2-a$ & $93.5 \mathrm{~A}$ & $6.5 \mathrm{~B}$ & 0.40 & 0.19 & 2.0 & - & - & & 0.08 & - \\
\hline $1-2-b$ & $93.5 \mathrm{~A}$ & $6.5 \mathrm{~B}$ & 0.37 & 0.22 & 2.2 & - & - & & 0.08 & \\
\hline $1-3-a$ & $93.5 \mathrm{~A}$ & $6.5 \mathrm{~B}$ & 0.40 & 0.20 & 1.9 & - & - & & 0.08 & - \\
\hline $1-3-b$ & $93.5 \mathrm{~A}$ & $6.5 \mathrm{~B}$ & 0.57 & 0.13 & 1.3 & - & - & & 0.08 & - \\
\hline $2-1-a$ & $93.1 \mathrm{~B}$ & $6.9 X^{(c)}$ & 0.73 & 0.20 & 2.2 & 5.59 & 5.31 & & 0.30 & - \\
\hline $2-1-b$ & $93.1 \mathrm{~B}$ & $6.9 \times$ & 1.09 & 0.16 & 1.6 & 5.59 & 5.31 & & 0.30 & - \\
\hline $2-2-a$ & $93.1 \mathrm{~B}$ & $6.9 \times$ & 0.95 & 0.18 & 1.7 & 8.23 & 4.11 & & 0.35 & 0.31 \\
\hline $2-2-b$ & $93.1 \mathrm{~B}$ & $6.9 x$ & 1.10 & 0.16 & 1.7 & 8.23 & 4.11 & & 0.35 & 0.31 \\
\hline $2-3-a$ & $93.1 \mathrm{~B}$ & $6.9 x$ & 0.83 & 0.25 & 2.4 & 6.05 & 6.22 & & 0.31 & 0.28 \\
\hline $2-3-b$ & $93.1 \mathrm{~B}$ & $6.9 \times$ & 0.49 & 0.20 & 1.9 & 6.05 & 6.22 & & 0.31 & 0.28 \\
\hline $3-1-a$ & $93.5 \mathrm{~B}$ & $6.5 \gamma^{(d)}$ & 0.97 & 0.19 & 1.9 & 7.14 & 6.42 & & 0.29 & 0.30 \\
\hline $3-1-b$ & $93.5 \mathrm{~B}$ & $6.5 Y$ & 0.62 & 0.28 & 2.7 & 7.14 & 6.42 & & 0.29 & 0.30 \\
\hline $3-2-a$ & $93.5 \mathrm{~B}$ & $6.5 Y$ & 0.61 & 0.23 & 2.3 & 6.68 & 7.12 & & 0.34 & 0.34 \\
\hline $3-2-b$ & $93.5 \mathrm{~B}$ & $6.5 Y$ & 0.87 & 0.19 & 1.7 & 6.68 & 7.12 & & 0.34 & 0.34 \\
\hline $3-3-a$ & $93.5 \mathrm{~B}$ & $6.5 Y$ & 0.51 & 0.21 & 2.1 & 6.05 & 5.32 & & 0.33 & 0.31 \\
\hline $3-3-b$ & $93.5 \mathrm{~B}$ & $6.5 Y$ & 0.48 & 0.20 & 2.0 & 6.05 & 5.32 & & 0.33 & 0.31 \\
\hline $3-3-c$ & $93.5 \mathrm{~B}$ & $6.5 Y$ & 1.15 & 0.82 & 7.6 & 5.82 & 5.32 & & 0.31 & - \\
\hline $3-3-d$ & $93.5 \mathrm{~B}$ & $6.5 Y$ & 1.11 & 0.78 & 7.4 & 5.82 & 5.32 & & 0.31 & - \\
\hline $4-1-a$ & $93.5 \mathrm{~A}$ & $6.5 \times$ & 0.52 & 0.22 & 2.1 & 7.29 & 8.14 & & 0.21 & 0.19 \\
\hline $4-1-b$ & $93.5 \mathrm{~A}$ & $6.5 \times$ & 0.47 & 0.20 & 1.8 & 7.29 & 8.14 & & 0.21 & 0.19 \\
\hline $4-2-a$ & $93.5 \mathrm{~A}$ & $6.5 \times$ & 0.37 & 0.22 & 2.1 & 7.44 & 5.78 & & 0.19 & 0.19 \\
\hline $4-2 \cdot b$ & $93.5 \mathrm{~A}$ & $6.5 \times$ & 0.48 & 0.26 & 2.5 & 7.44 & 5.78 & & 0.19 & 0.19 \\
\hline $4-3-a$ & $93.5 \mathrm{~A}$ & $6.5 \times$ & 0.29 & 0.23 & 2.2 & 7.34 & 7.44 & & 0.19 & 0.20 \\
\hline $4-3-b$ & $93.5 \mathrm{~A}$ & $6.5 \times$ & 0.25 & 0.21 & 2.0 & 7.34 & 7.44 & & 0.19 & 0.20 \\
\hline $4-3-c$ & $93.5 \mathrm{~A}$ & $6.5 \times$ & 0.36 & 0.18 & 1.7 & 7.34 & 7.44 & & 0.20 & - \\
\hline $4-3-d$ & $93.5 \mathrm{~A}$ & $6.5 \times$ & 0.20 & 0.18 & 1.7 & 7.34 & 7.44 & & 0.20 & - \\
\hline $5-1-a$ & $93.5 \mathrm{~A}$ & $6.5 Y$ & 0.42 & 0.23 & 2.1 & 7.37 & 7.32 & . & 0.15 & 0.17 \\
\hline $5-1-b$ & $93.5 \mathrm{~A}$ & $6.5 Y$ & 0.66 & 0.21 & 2.2 & 7.37 & 7.32 & & 0.15 & 0.17 \\
\hline $5-2-a$ & $93.5 \mathrm{~A}$ & $6.5 Y$ & 0.50 & 0.21 & 2.0 & 8.69 & 7.60 & & 0.16 & 0.17 \\
\hline $5-2-b$ & $93.5 \mathrm{~A}$ & $6.5 Y$ & 0.67 & 0.20 & 1.8 & 8.69 & 7.60 & 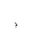 & 0.16 & 0.17 \\
\hline $5-3-a$ & $93.5 \mathrm{~A}$ & $6.5 Y$ & 0.92 & 0.20 & 2.1 & 12.98 & 8.79 & & 0.21 & 0.22 \\
\hline $5-3-b$ & $93.5 \mathrm{~A}$ & $6.5 Y$ & 0.44 & 0.23 & 2.3 & 12.98 & 8.79 & & 0.21 & 0.22 \\
\hline
\end{tabular}

(a) $50 \mathrm{KCl}-50 \mathrm{NaCl}$.

(b) $50 \mathrm{KCl}-50 \mathrm{Na}_{2} \mathrm{CO}_{3}$.

(c) $44 \mathrm{Li}_{2} \mathrm{CO}_{3}-56 \mathrm{~K}_{2} \mathrm{CO}_{3}$.

(d) $25 \mathrm{Li}_{2} \mathrm{CO}_{3}-75 \mathrm{~K}_{2} \mathrm{CO}_{3}$. 

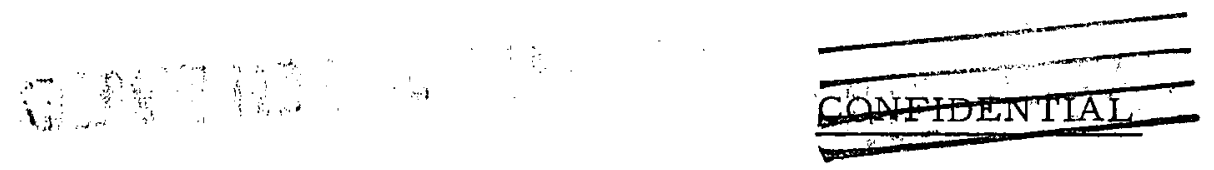

$\mathrm{B}-2$

TABLE B-2. MAXIMUM CORROSION OBSERVED

ON EACH CORROSION SPECIMEN(a)

\begin{tabular}{|c|c|c|}
\hline Specimen & Salt Bath(b) & $\begin{array}{c}\text { Maximum Corrosion } \\
\text { Observed, in. }\end{array}$ \\
\hline \multirow{5}{*}{ Mild steel } & 1 & 0.021 \\
\hline & 2 & $0.087^{(\mathrm{c})}$ \\
\hline & 3 & $0.099(\mathrm{c})$ \\
\hline & 4 & 0.023 \\
\hline & 5 & 0.028 \\
\hline \multirow[t]{7}{*}{ Type 304 stainless steel } & 1 & 0.003 \\
\hline & 2 & $0.125^{(d)}$ \\
\hline & 3 & $0.096(d)$ \\
\hline & 4 & 0.014 \\
\hline & & 0.010 \\
\hline & $5(e)$ & 0.006 \\
\hline & $5(f)$ & 0.002 \\
\hline \multirow[t]{5}{*}{ Type 330 stainless steel } & 1 & - \\
\hline & 2 & 0.005 \\
\hline & 3 & 0.003 \\
\hline & 4 & 0.002 \\
\hline & 5 & 0.002 \\
\hline \multirow[t]{5}{*}{ Type 416 stainless steel } & 1 & -- \\
\hline & 2 & -- \\
\hline & 3 & 0.024 \\
\hline & 4 & 0.013 \\
\hline & 5 & 0.015 \\
\hline \multirow[t]{5}{*}{ Type 446 stainless steel } & 1 & -- \\
\hline & 2 & -- \\
\hline & 3 & $>0.016$ \\
\hline & 4 & $0.009(\mathrm{~g})$ \\
\hline & 5 & $0.011(g)$ \\
\hline
\end{tabular}

(a) Maximum attack observed occurred below salt bath level except where noted. Specimens in salt bath 3 weeks except where noted.

(b) Salt bath compositions:

Bath 1. 93.5 w/o $(50 \mathrm{KCl}-50 \mathrm{NaCl})-6.5 \mathrm{w} / \mathrm{o}\left(50 \mathrm{KCl}-50 \mathrm{Na}_{2} \mathrm{CO}_{3}\right)$

Bath 2. $93.1 \mathrm{w} / \mathrm{o}\left(50 \mathrm{KCl}-50 \mathrm{Na}_{2} \mathrm{CO}_{3}\right)-6.9\left(44 \mathrm{w} / \mathrm{o} \mathrm{Li} 2 \mathrm{CO}_{3}-56 \mathrm{~K}_{2} \mathrm{CO}_{3}\right)$

Bath 3. $93.5 \mathrm{w} / \mathrm{o}\left(50 \mathrm{KCl}-50 \mathrm{Na}_{2} \mathrm{CO}_{3}\right)-6.5 \mathrm{w} / \mathrm{o}\left(25 \mathrm{Li}_{2} \mathrm{CO}_{3}-75 \mathrm{~K}_{2} \mathrm{CO}_{3}\right)$

Bath 4. 93.5 w/o (50 KCl-50 NaC1) - $6.5 \mathrm{w} / \mathrm{o}\left(44 \mathrm{Li}_{2} \mathrm{CO}_{3}-56 \mathrm{~K}_{2} \mathrm{CO}_{3}\right)$

Bath 5. $93.5 \mathrm{w} / \mathrm{o}(50 \mathrm{KCl}-50 \mathrm{NaCl})-6.5 \mathrm{w} / \mathrm{o}\left(25 \mathrm{Li}_{2} \mathrm{CO}_{3}-75 \mathrm{~K}_{2} \mathrm{CO}_{3}\right)$

(c) Corrosion took place between salt bath level and bottom of condensed salt crust.

(d) Deep irregular pits $1 / 4$ in. or more wide across face of specimen ( 1 in.). Some occurred right under salt-bath level, some at the lower end of the specimens, and some just above the salt-bath level.

(e) This specimen in salt bath for 1 week.

(f) This specimen in salt bath for 2 days.

(g) Selective penetration occurred throughout the remaining metal.

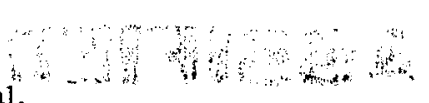


TABLE B-3. HYDROGEN CONTENT OF 10 URANIUM SPECIMENS NOT HEAT TREATED(a)

\begin{tabular}{c}
\hline Hydrogen Content, ppm \\
\hline 0.58 \\
0.27 \\
0.41 \\
0.20 \\
0.20 \\
0.18 \\
0.22 \\
0.28 \\
0.22 \\
0.15 \\
\hline
\end{tabular}

(a) These specimens selected at random from approximately 80 specimens available for heat treating. 